\title{
Shallow Subsurface Evidence for Postglacial Holocene Lakes at Ivanpah Dry Lake: An Alternative Energy Development Site in the Central Mojave Desert, California, USA
}

\author{
Douglas B. Sims ${ }^{1} \&$ W. Geoffrey Spaulding ${ }^{2}$ \\ ${ }^{1}$ Department of Physical Sciences, College of Southern Nevada, North Las Vegas, USA \\ ${ }^{2}$ Terra Antiqua Research, Henderson, USA \\ Correspondence: Douglas B. Sims, Department of Physical Sciences, College of Southern Nevada, North Las \\ Vegas, Nevada 89030, USA. E-mail: douglas.sims@csn.edu
}

Received: December 29, 2016

Accepted: January 11, 2017

Online Published: January 31, 2017

doi:10.5539/jgg.v9n1p1

URL: http://dx.doi.org/10.5539/jgg.v9n1p1

A portion of this research (students) was funded by the NASA-CoP Grant (NNX14Q94A).

\begin{abstract}
Dry lakes, or playas, in the American Southwest have become important locations for alternative energy solar electric generation systems. Many of these playas have not been investigated for past environmental conditions prior to their development, causing alterations to the shallow sediment profile and altering subsurface chemical and physical data important to recent geologic and hydrologic histories of these areas. Recent studies of these features commonly have focused on surficial data with little or no subsurface geologic data to delineate wet and dry cycles of playa lakes. Many of the playa margins are covered with a surficial layer of alluvial and/or aeolian sands varying in thickness, which could interfere with correct interpretations of data gathered only on the surface material on these lands. Over the past 13,000 years Ivanpah Dry Lake has had at least three episodes of lake highstands up to $\sim 10 \mathrm{~m}$ in response to climate changes, based on data in this study with the oldest episode dates to $\sim 13,000$ cal yrs BP. This study has a link to other sites as many other playas are slated for energy development and could endure subsurface data alteration during site reworking and occupation, resulting in a loss in their collective historical geologic and hydrologic records if more complete studies of important sites are not carried out before developments begin.
\end{abstract}

Keywords: Ivanpah, pluvial lakes, playa, Lake Mojave, Holocene, Pleistocene, lacustrine, California

\section{Introduction}

Desert dry lakes and their margins in the American Southwest and elsewhere are considered potential sites for the development of alternative energy projects to supplant current energy sources that adversely affect climate, and climate change awareness in action policies by potentially affected institutions. Many of these areas are located within regions where there has been little focus into historical environmental conditions. In response to increased alternative energy needs, there are strategies in place to create solar energy zones that encroach onto and could disturb buried deposits across the deserts of the American Southwest, including Ivanpah Dry Lake (Fig. 1) ("Lake Ivanpah"). These developments are impacting the very sedimentological records that could provide information on the historical environmental conditions, and potential future environmental impacts. In other words, it seems that the vast magnitude of paleohydrologic changes that can occur in these basins is under-appreciated when facilities performance over decades are considered.

Understanding long-term environmental change in the arid Southwest rests in part on paleohydrologic studies, mostly of the Quaternary Period, pluvial lakes fed by rivers originating from beyond the desert (e.g. Blunt and Negrini, 2015; Enzel et al., 2003; Litwin et al., 1999; Nishizawa, 2010; Negrini et al., 2006; Wells et al., 2003), and paleospring deposits that reflect more local histories of recharge within the Great Basin and Mojave deserts (Quade et al., 1995; 2003). Such records of hydrologic responses to precipitation allow for greater delineation of the effects of changing climate. The effects of these changes have been profound on both surface processes and biotic communities in the region (e.g., Bull 1991; Spaulding 1990). 


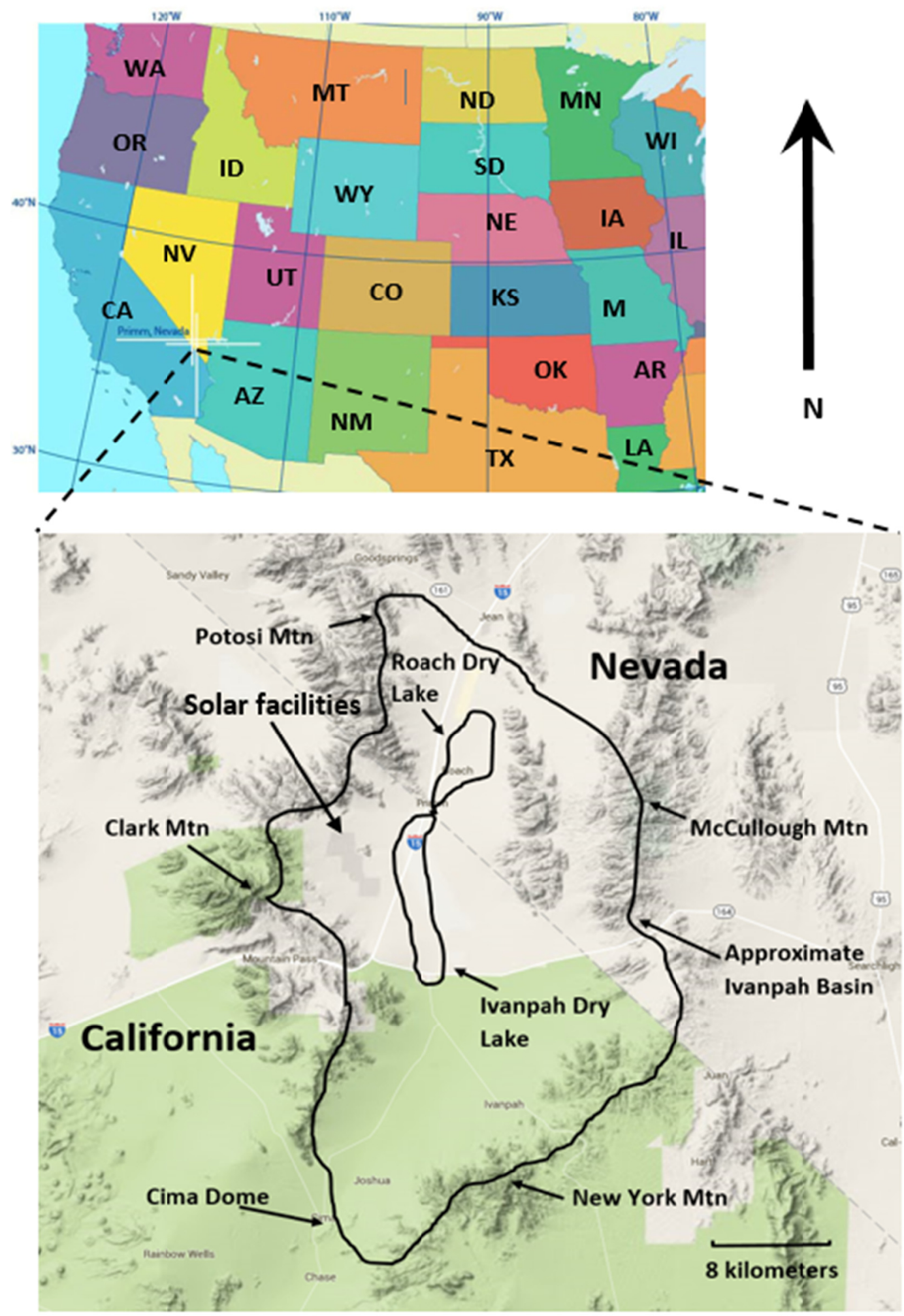

Figure 1. Location of Lake Ivanpah, California and approximate Ivanpah hydrologic basin

Desertification of the American Southwest followed the retreat of the continental ice sheets in the Northern Hemisphere, as an increase in thermal regimes accompanied a northward shift in circulation patterns to those characteristic of the present arid Southwest (Thompson et al., 1993). There have been studies in this region of late Quaternary Period precipitation and its effects on groundwater, climate change, and pluvial lake systems 
(Quade et al., 1995; Pigati et al., 2011; Waring, 1920; Wells et al., 2003). Other research in this area evaluated Pleistocene Camelid tracks and aeolian distributions as they relate to climate change at Mesquite Lake, California, a dry lake system located $16.5 \mathrm{~km}$ northwest of Primm, Nevada (Shapiro, 2016; Whitney et al., 2015). Finally, environmental variability within this region, and more notably, Ivanpah Valley, is complex.

To better appreciate the environmental changes inherent to Lake Ivanpah, it is important to recognize that episodes of higher lake stands and increased paleospring discharge, occurred not only during the latest Pleistocene, but also during the succeeding Holocene (e.g. Wells et al., 2003; Noble et al., 2016; Quade et al., 1995; Pigati et al., 2011). The Pleistocene to Holocene transitional period experienced reversals in the desiccation of ancient lakes and extinct spring systems ("paleolakes" and "paleosprings"). So, while it has been reported that the "final" desiccation of paleolakes and ancient springs occurred between ca. 9,300 and 7,800 calibrated years BP (cal yrs BP), essentially concordant with the extirpation of mesic vegetation in current deserts (Wells et al., 2003; Pigati et al., 2011; Spaulding and Graumlich, 1986), there were important reversals during the succeeding postglacial. According to Noble et al. (2016), pluvial events of sufficient magnitude to fill some basins for decades or centuries occurred during the middle and late Holocene. Refilling of basins along the Mojave River reportedly occurred at least twice: ca. 3,600 yrs BP and again during the Little Ice Age, ca. 600 to 200 yrs BP (Enzel et al., 1992; Tchakerian and Lancaster, 2002). Other studies documented that the late Holocene Period witnessed a rebirth of paleospring systems throughout this region (e.g. Mehringer and Warren, 1976; Jones et al., 1999).

There has been comparatively little research on dry lakes with drainage basins lying entirely within the Mojave Desert. Unlike lakes Owens and Searles, on the Owens River that heads in the eastern Sierra Nevada, or Lakes Manix and Mojave on the Mojave River that heads in the Transverse Ranges, isolated dry lake basins show few geomorphological signs of highstands (i.e. wave-cut benches), fluvial deposits and/or terraces (Mifflin and Wheat, 1979; Reheis and Redwine, 2008). Comparing the apparent absence of pluvial lakes in the southern Great Basin to their relative abundance and great size in the north, Mifflin and Wheat (1979) developed a model relating the combined effects of an increased thermal regime in the south, lower elevations, and smaller mountains to insufficient runoff to support persistent lakes, even during glacial conditions. As a result, little research has focused on the paleohydrology of internal dry-lakes of the southern Great Basin. Studies have shown that the mere absence of surface evidence does not preclude the possibility of ancient lakes. Rather, studies require interpretation from the examination of aeolian dunes, infrared photographs, subsurface conditions, grain size, and sediment chemistry-proxy data to identify buried remnants of ancient lake beds (Sack, 1995; 2001).

\section{Environmental Setting}

Three solar electric energy generation projects are currently being built, or operational, in the Ivanpah Valley in the last five years. In order of their proximity (farthest from) to the current playa margin are: Stateline Solar Farm Development on the northeastern margin of Lake Ivanpah, on the toe of the Clark Mountain alluvial fan in California; Silver State and Silver State South Solar Energy Centers, east of Roach Dry Lake, northern portion of the Lucy Gray alluvial fan toe in Nevada; and Ivanpah Solar Electric Generating System, located further up the Clark Mountain alluvial fan. The Ivanpah facility is currently the world's largest concentrated solar thermal power station in operation while the other two facilities are large solar photovoltaic systems (CH2MHILL, 2009).

\subsection{Hydrologic Setting}

Although the Ivanpah basin is not part of the Mojave River drainage (see Enzel et al., 2003), tributaries to the lower Mojave River lie only $\sim 25 \mathrm{~km}$ to the west in Shadow Valley. Approximately $20 \mathrm{~km}$ to the east on the other side of the McCullough Mountains, the Paiute Valley drains into the Colorado River. The Ivanpah basin incorporates a drainage network extending from the Teutonia Peaks area on Cima Dome, $25 \mathrm{~km}$ to the southwest in California, to Potosi Mountain, about $40 \mathrm{~km}$ to the east-northeast in the Spring Mountains of Nevada (Fig. 1). The watershed also includes the north flank of the New York Mountains and Mid Hills to the south and southwest. The Ivanpah Range, Mescal Range, and Clark Mountain provide runoff from the west, and, the Clark Mountain Range and southern-most Spring Mountains provide runoff from the north.

The Ivanpah basin also includes Roach Dry Lake, immediately to the northeast in Nevada, separated from Ivanpah playa only by the toe of the alluvial fan extending west from the Lucy Gray Mountains. Because this permeable sill is the only separation between the two playas, Roach Dry Lake and its drainage are part of the Ivanpah hydrologic system. Other studies of the hydrological processes of Lake Ivanpah have determined that Ivanpah Valley is entirely internally drained (House et al., 2010). Lake Ivanpah's surface drainage in California 
is approximately $1,128 \mathrm{~km}^{2}$; its catchment in Nevada is approximately $831 \mathrm{~km}^{2}$, for a total drainage basin area of $1,959 \mathrm{~km}^{2}\left(756 \mathrm{mi}^{2}\right)$. The surface area of Ivanpah playa is about $53 \mathrm{~km}^{2}$ while Roach playa is approximately 15 $\mathrm{km}^{2}$.

\subsection{Topographic Setting}

Ivanpah playa has a sinusoidal shape that is the result of two large alluvial fans intruding on its margins from the northeast and from the west; i.e. Lucy Gray and Wheaton Wash alluvial fans (Figs. 1-3). Both alluvial fans create a convex-shaped shoreline at their terminal edges. The arcuate margin of Lucy Gray Fan terminal edge projects west and extends for $\sim 5 \mathrm{~km}$ south of the sill it creates, terminating at the playa in the north. Approximately 10 $\mathrm{km}$ south, on the opposed side of the playa, the toe of the Wheaton Wash Fan forms an eastward projecting convex shoreline. Fans are composed of moderately sorted, well stratified sands and gravels of pebble and boulder sizes with minor amounts of aeolian silts and sands at depth, with an estimated age of deposits of $\sim 2.6$ million years according to House et al. (2010). Both the Lucy Gray and Wheaton Wash Fan are lacking active fluvial processes, with recent flows confined to ephemeral systems nearer the source of materials (House et al., 2006; 2010).

The relief of the topography encompassing a basin's drainage is a critical factor in determining runoff; i.e. the higher mountains cause greater amounts of orographically induced precipitation (Mifflin and Wheat, 1979). Studies of Mojave River runoff for instance, show that water contained in Lake Mojave originated chiefly from surrounding mountains outside the Mojave Desert (Enzel et al., 2003). With the Mojave River in mind, the Ivanpah drainage basin includes some of tallest mountain ranges in the central Mojave Desert (i.e. New York Mountains $[\sim 2,296 \mathrm{~m}]$, Clark Mountain $[\sim 2,417 \mathrm{~m}]$, Potosi Mountain in the southern Spring Mountains $[\sim 2,595 \mathrm{~m}]$, and $\sim 2,142 \mathrm{~m}$ for McCullough Mountain) and therefore, runoff that entered the Ivanpah basin originates from the surrounding mountains.

The barren part of Ivanpah Basin's elongate and sinusoidal playa occupies only the northern $55 \%$ of the 19.3 $\mathrm{km}$-long basin floor. Generally not more than $3 \mathrm{~km}$ wide, the playa extends south about $11 \mathrm{~km}$ from the vicinity of Primm, Nevada, to an ill-defined southern limit at about the $795 \mathrm{~m}$ contour. The barren northern and central portions of the playa are mapped as essentially level at $794 \mathrm{~m}$ amsl (USGS, 1985). The playa surface continues farther south, but is mantled by an increasingly dense cover of saltscrub hummocks to the south. These hummocks, usually not exceeding a meter in height, consist of grey-brown to pale brown (10YR7/4), silty fine sand anchored by saltscrub vegetation, and typified by Allscale (Atriplex polycarpa), a species of saltbush. South of the Nipton Road, blow-outs that have stripped back the mantling saltscrub hummocks reveal a mosaic of playa surface and carbonate-rich paleospring outcrops armored by nodular tufa concretions (Robinson et al., 1999). Saltscrub rims the entire playa except for its north end, and it gives way upslope to a creosote bush (Larrea tridentata) - Burrobush (Ambrosia dumosa) scrub transition zone.

Moving south, the floor of Ivanpah playa rises in elevation well before its southern end is reached. Because the surface of Ivanpah playa is not level, evidence of shallow water in the south indicates deeper water to the north. Previous research near Nipton Road identified oxidized lake muds in yardangs at $800.1 \mathrm{~m}$ amsl, only $\sim 0.9 \mathrm{~m}$ above the adjacent playa but $>6 \mathrm{~m}$ above the elevation of the pan in the north (Robinson et al., 1999). Their investigation found bedded, sandy alluvium yielding abruptly to a charcoal-rich, dark-grey lake mud at $\sim 1 \mathrm{~m}$ depth. The top of this lake mud was surveyed at $799.9 \mathrm{~m}$ amsl, again $\sim 6 \mathrm{~m}$ above the playa floor in the northern Ivanpah basin, yielding an age of $9,560 \pm 70{ }^{14} \mathrm{C}$ yrs BP (Robinson et al., 1999). Assuming inundation is needed for playa-mud deposition, and that no substantial tectonic warping of the basin floor has occurred, their study indicated that a lake of at least moderate depth occupied the northern Ivanpah basin.

There is no abrupt southern boundary to Ivanpah playa. Rather, it is characterized by an increasingly dense cover of saltscrub hummocks and tongues of gravelly alluvium, the latter from the broad delta-fan expanding onto the basin floor from the south at the mouth of Cima Wash. The name Cima Wash was applied to the system of anastomosing sandy washes that extends $\sim 25 \mathrm{~km}$ south and west from the southern playa margin to the southeast flank of Cima Dome. As this broad drainage runs down the southwestern Ivanpah Valley, it is joined by washes draining the north flank of the New York Mountains and Mid-Hills. Remote imagery and field assessment places the distal toe of the Cima Wash delta-fan, and the southern limit of Ivanpah playa, $\sim 1 \mathrm{~km}$ south of Nipton Road.

\subsection{Ivanpah Playa}

The location of Lake Ivanpah is a topographic depression at the base of the Ivanpah, Mescal, and Clark Mountain ranges, just west of the Nevada state line. The study area is hot and dry with temperatures fluctuating between $\sim 1^{\circ} \mathrm{C}$ in winter (January/December) to $>41^{\circ} \mathrm{C}$ in summer (July/August). Precipitation averages $<11.5 \mathrm{~cm}$ annually near the basin bottom and higher in the surrounding mountain ranges (Robinson et al., 1999). 
Geographically, this relatively high basin (playa surface is $\sim 794 \mathrm{~m}$ above mean sea level [amsl]) is located within the Mojave Desert. Roach Dry Lake is connected to the Ivanpah playa at the border of Nevada and California (Primm, NV) and is part of the Ivanpah Catchment Basin. It lies at $\sim 794 \mathrm{~m}$ amsl and is separated from Ivanpah by a narrow sill produced by the merger of the Lucy Gray alluvial fan and a limestone ridge extending south from the Spring Mountains Range (Carr and Pinkston, 1987; Garside et al., 2009). The Ivanpah catchment in California is approximately $1,128 \mathrm{~km}^{2}$ with the Nevada portion being $\sim 831 \mathrm{~km}^{2}$ (totaling $\sim 1,959 \mathrm{~km}^{2}$ ) with Ivanpah playa covering $\sim 53 \mathrm{~km}^{2}$ and Roach playa $\sim 15 \mathrm{~km}^{2}$.

Lacustrine sediments have been described as having distinct lithological units with defined beds (laminated) of reworked material containing ubiquitous amounts of carbonates, much greater than sediment organic carbon, with large amounts of soluble salts (Eugster and Kelts, 1983). Other authors have defined lacustrine sediments as originating from incoming sediments due to wetting events, depositing sediments in an aqueous environment which in turn becomes a playa surface with aridity (Kliem et al., 2012; May et al., 2015). Thus, the superficial portion of a lacustrine unit will appear as a classic playa surface, the upper most portion of a lacustrine unit according to Kliem et al., (2012).

\subsection{Ancient Shorelines and Lacustrine Features}

Identifying, correlating and mapping shoreline features in an area where the climate has been relatively stable since the end of the Pleistocene can be challenging (Sack, 1995). Shorelines usually leave demarcations ("highstands") of their farthest advance and later, may be buried or obliterated by successional advances but leaving visible geomorphic evidence (Adrian et al., 1999). Ivanpah has no such obvious preserved visible lake highstands as describe by other authors (i.e. Negrini et al., 2006; Enzel et al., 1992; Wells et al., 2003). Studies have however, documented the reworking and/or burial of shorelines and their associated lacustrine sediments by active alluvial fans and evidence of fluvial and aeolian processes that obliterate and bury geomorphic evidence making them difficult to locate surficially with aerial photographs, topographic maps and ground reconnaissance activities (Sack, 1995).

There was surficial geological mapping of portions of this basin that identified no obvious ancient shorelines (House et al., 2010; 2006; Ramelli et al., 2006; Schmidt et al., 2006). These studies however did map "playa fringe deposits" to elevations $>10 \mathrm{~m}$ above the current playa margin. Visual evidence in the form of shorelines is only one factor in pluvial lake demarcation: soils, sedimentologic, sediment chemistry, subsurface stratigraphy, and geomorphic evidence also can be used to identify pluvial lakes lacking obvious shorelines (Sack, 1995; 2001; Schnurrenberger et al., 2003). Current efforts do not contradict prior mapping efforts (House et al., 2010, 2006; Ramelli et al., 2006; Schmidt et al., 2006), but are complementary to them. However, because the possibility of a pluvial lake having occupied the basin is absent from their interpretive geological framework (House et al., 2010, 2006; Ramelli et al., 2006; Schmidt et al., 2006.), and because their work was restricted to the Nevada portion of the basin, those data sets have limited transfer value to this effort.

Within the Ivanpah basin nonetheless, there are yardangs, loose and un-weathered surface sand, strath surfaces (Fig. 2A), hummocks (Fig. 2B), both modern (Fig. 2C) and ancient (Fig. 2D) beach surfaces, north-south trending low lying aeolian dunes (Fig. 2E) with discontinuous sand sheets, and exposed lacustrine sediments just off the perimeter of the playa margin. These features are subtle evidence of preserved landforms that could easily be overlooked by analysis of aerial photography and topographic map review, even supported with some ground reconnaissance. This research does not map geomorphic evidence on the surface, but rather, evaluates subsurface conditions at one location on the eastern side of Lake Ivanpah.

\section{Objectives}

The purpose of this research is to demonstrate that a large (depth $>5 \mathrm{~m}$ ) body of water episodically occupied the basin in lieu of a pluvial lake, and expanded well beyond the edge of the current playa as supported predominantly by data gathered from subsurface sediments. To do this, subsurface conditions on the playa margins were investigated using sedimentary stratigraphy and chemical proxies to identify subsurface anomalies potentially related to lake transgressions over alluvial fan toes. These chemical proxies (metals, $\mathrm{SO}_{4}{ }^{2-}, \mathrm{Cl}^{-}$, $\mathrm{CaCO}_{3}, \mathrm{pH}, \mathrm{Mg} / \mathrm{Ca}$ ratios, radiocarbon dating $\left({ }^{14} \mathrm{C}\right), \delta^{13} \mathrm{C}$, and $\left.\delta^{18} \mathrm{O}\right)$ were used to locate a suitable location for further excavation so that subsurface sedimentological, geomorphic, and lacustrine event evidence could establish chronology, and be used to describe the magnitude of environmental change within the Ivanpah basin. Data was comparable with records of lake-level changes from other paleolakes, particularly those that received most of their runoff from mountains both inside and outside the Mojave Desert. 


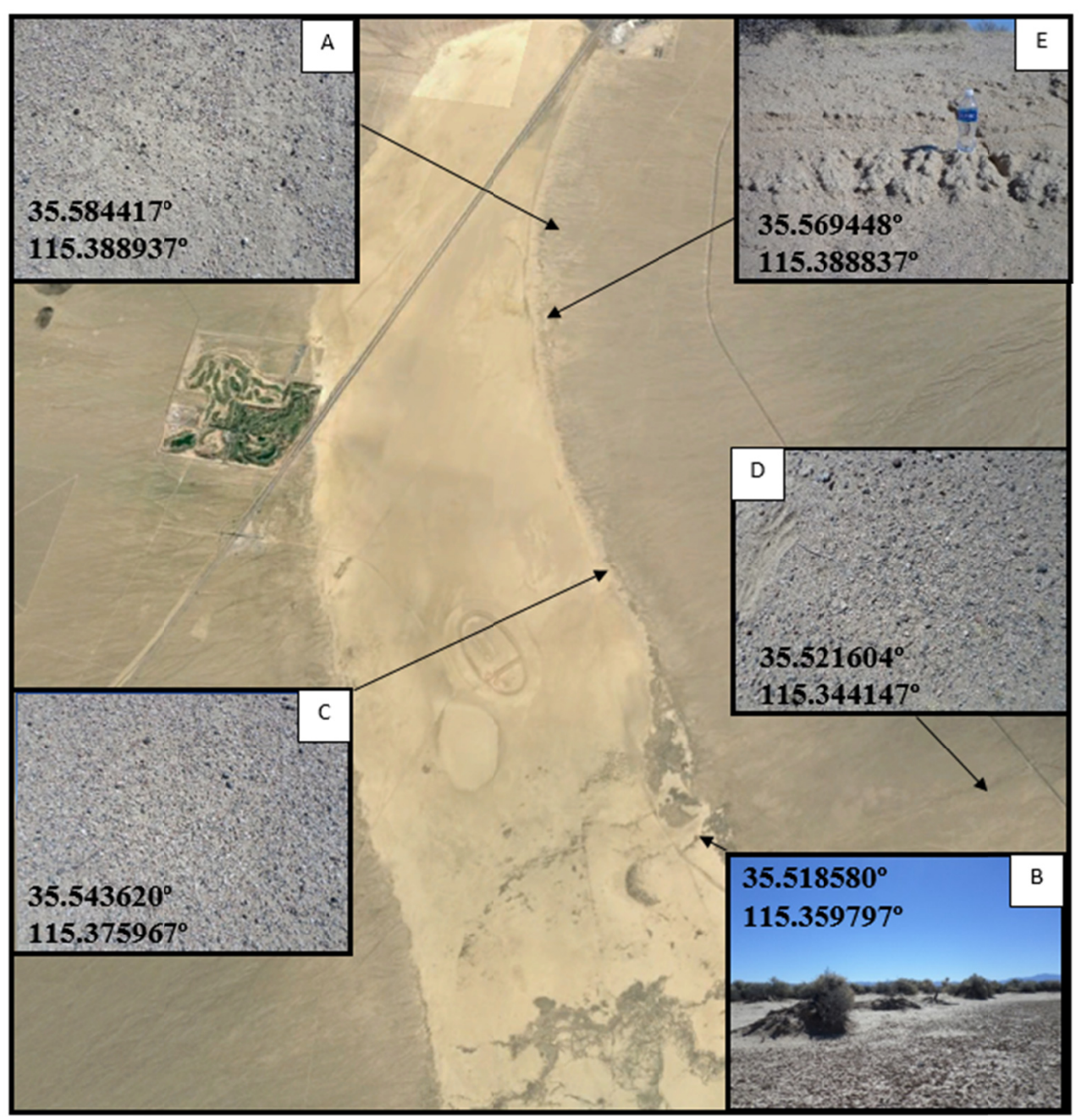

Figure 2. Subtle geomorphic evidence across Lake Ivanpah

\section{Methods and Materials}

\subsection{Field Sampling Methods}

Methods employed are similar to Rodrigues-Filho and Muller (1999) and adapted for this region and environment. Their study involved coring to a depth of $12 \mathrm{~m}$ with mechanical assistance for sediment characterization. This study was however, limited to hand-driven cores by the BLM due to the culturally sensitive environment of the eastern side of Ivanpah. With this limitation, coring was used only for the identification of subsurface anomalies and to determine the optimal location for further excavation for sediment characterization.

The eastern side of Ivanpah was chosen for this study because the western side of the lake has been heavily impacted by large solar energy projects (Fig. 3A). The first phase consisted of the 12 shallow cores to $\sim 50 \mathrm{~cm}$ depth (see supplementary data for geolocations) starting near the center of the dry lake and moving eastward onto the Lucy Gray Mountains bajada (Fig. 3B). Core samples were collected with a hand driven portable AMS hollowstem auger $(2.54 \mathrm{~cm} \times 60 \mathrm{~cm})$ kit with a split spoon insert and a high-density polyethylene (HDPE) liner to collect a continuous $50 \mathrm{~cm}$ profile. Liners were removed, capped and placed in a cooler for transport to the laboratory. After cores were analyzed and an anomaly was identified (chemical proxy), one location (LGL 5) was excavated by hand to $1.96 \mathrm{~m}$ bgs to identify and document substrata features where chemical proxies (the anomaly) were identified. LGL 5 substrata were described and catalogued so that the processes that emplaced the fluvial and aeolian sediments could be linked by their depositional development and chemical proxies detected. 


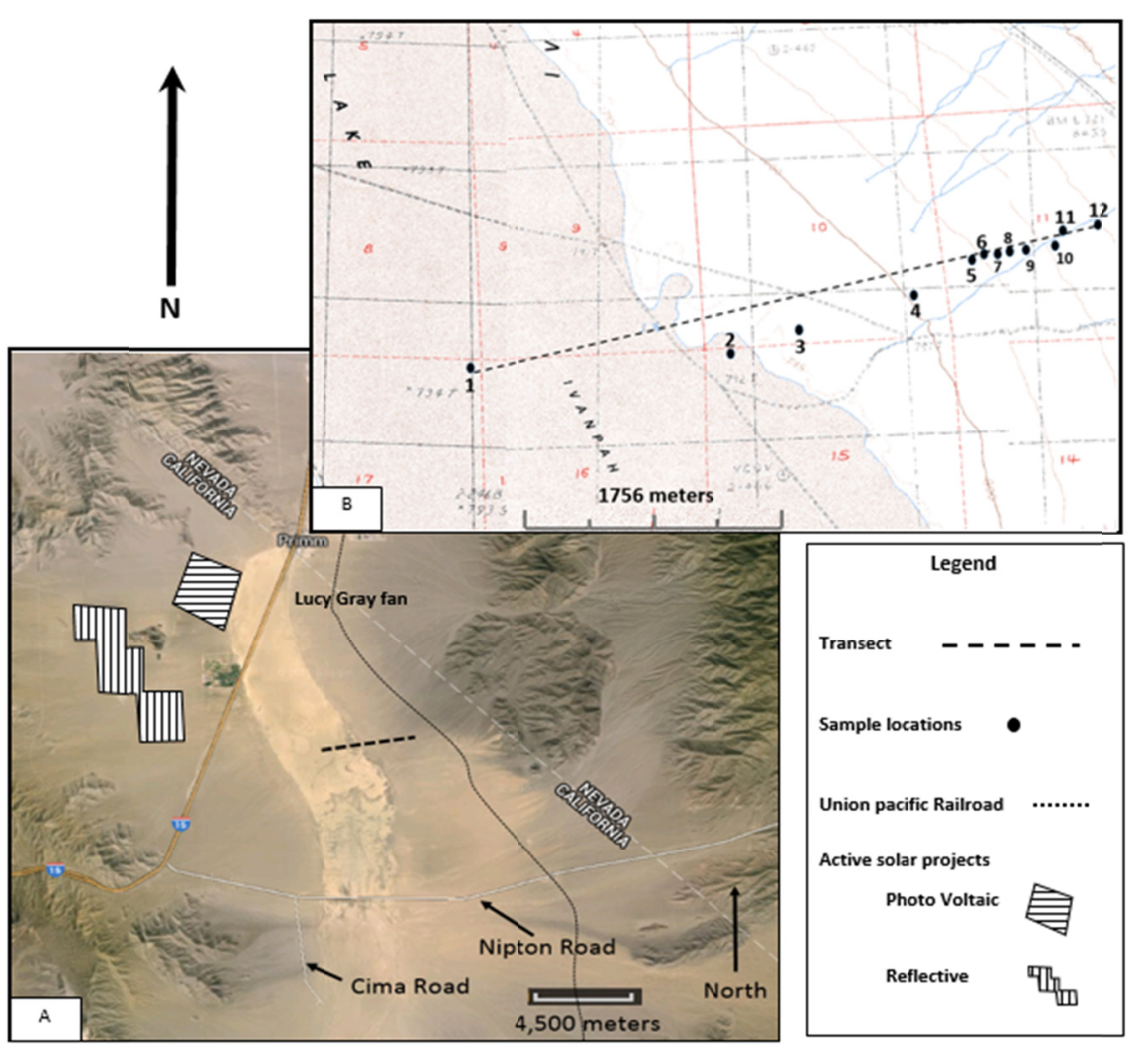

Figure 3. Aerial overview of Lake Ivanpah and features

Note: (A); Lucy Gray Transect (LGL) and sample locations (B). Lat./Long. for locations (1-12) are available in suplamentary data.

Samples were collected between May 2014 and December 2015 from lands administered by the United State Department of Interior, Bureau of Land Management (BLM), Needles, California, Field Office. The approach was designed to assess chemical proxies such as trace metals (As, $\mathrm{Ba}, \mathrm{Cr}, \mathrm{Cu}, \mathrm{Li}, \mathrm{Mn}, \mathrm{Ni}, \mathrm{Pb}, \mathrm{Ti}, \mathrm{V}$ ) and crustal metals $(\mathrm{Al}, \mathrm{Ca}, \mathrm{Fe}, \mathrm{K}, \mathrm{Mg}, \mathrm{Zn})$ and wet chemistry $\left(\mathrm{Cl}^{-}, \mathrm{SO}_{4}{ }^{2-}, \mathrm{pH}, \mathrm{CaCO}_{3}\right), \mathrm{Mg} / \mathrm{Ca}$ ratios, $\mathrm{C}^{14}, \delta^{13} \mathrm{C}$ and $\delta^{13} \mathrm{O}$ in sediments across a $\sim 4.5 \mathrm{~km}$ transect.

Google Earth was not utilized for surface elevations within the Ivanpah basin because of an error observed. To plot sampling locations and the single excavation site accurately, each sampling site was recorded with a Trimble Survey R10 GNSS rover and base station receiver, GLONASS L1/L2 signal, Trimble HD-GNSS ${ }^{\mathrm{TM}}$ processing engine, Trimble SurePoint ${ }^{\mathrm{TM}}$ electronic bubble and traceable tilt values with a Trimble 360 satellite tracking. The Trimble $\mathrm{xFill}{ }^{\mathrm{TM}}$ is designed to work in radio and cellular black spots with an accuracy of $\pm 0.1 \mathrm{~m}$ with all locations tied to United States Geological Survey benchmarks.

\subsection{Laboratory Procedure}

Each core sample was dissected into $10 \mathrm{~cm}$ sections to provide separate data locations at depth. Core dissection was performed by scoring around the HDPE insert, then breaking at the scoring location so that each $50 \mathrm{~cm}$ core could be processed as $10 \mathrm{~cm}$ sections $(0-10,10-20,20-30,30-40,40-50)$, resulting in 60 separate samples along the LGL transect. Sediment samples were removed from each section, placed in clean HDPE sample containers, marked with location and depth, and transported to the laboratory.

\subsection{Metals Analysis}

Researchers Rodrigues-Filho and Muller (2001) have demonstrated that chemical weathering in saturated sediments causes the accumulation of less mobile metals and soluble constituents in a horizontally bedded fashion. Horizontally distributed metals in lake bed sediments are described by Rodrigues-Filho and Muller $(1999)$ as a reliable indicator of previous lake bed features. Therefore, trace elements (As, $\mathrm{Ba}, \mathrm{Cr} . \mathrm{Cu}, \mathrm{Li}, \mathrm{Mn}, \mathrm{Ni}$ $\mathrm{Pb}, \mathrm{Ti}, \mathrm{V})$ and crustal metals $(\mathrm{Al}, \mathrm{Ca}, \mathrm{Fe}, \mathrm{K}, \mathrm{Mg}, \mathrm{Zn}$ ) in sediments were analyzed using United States Environmental Protection Agency (USEPA) Solid Waste 846 (SW-846) protocols (USEPA, 1997) were 
performed at the College of Southern Nevada. These protocols included quality control measures to validate data integrity. Sediment samples ( $\sim$ gram) were digested by USEPA method 3050B (hot aqua-regia digestion), diluted to $50 \mathrm{ml}$ after digestion with deionized water, allowed to cool, settle, then filtered to remove particulate matter. Analysis was performed according to USEPA method 6010B; inductively coupled plasma-optical emission spectrometer.

Instrument calibration consisted of six points across a concentration range, including a blank, with a linear regression $\left(\mathrm{R}^{2}\right)$ of $>0.995$ (USEPA, 1997). Analytical integrity was further verified by using a USEPA certified reference sample (RTC Corporation: CRM022-020, Sample 5, lot D522) purchased from a USEPA certified reference laboratory. The certified reference sample measures within specified windows $( \pm 15 \%)$ and cannot exceed specified requirements. Additionally, samples were analyzed in triplicate with a required USEPA relative percent difference (RPD) of $<20 \%$ (USEPA, 1997).

\subsection{Wet Chemistry}

Analysis for wet chemistry were performed at the College of Southern Nevada. Sediment $\mathrm{pH}$ is an important measurement for assessing potential availability of beneficial nutrients in sediment. USEPA method 9045 was applied using a $\mathrm{H}^{+}$ion-selective glass electrode in a saturated paste to measure sediment $\mathrm{pH}$ (USEPA, 1997). The $\mathrm{pH}$ meter was calibrated by selection of $\mathrm{pH}$ standards that bracketed the sediment $\mathrm{pH}$ and measured to within 0.1 standard units.

Sulfate $\left(\mathrm{SO}_{4}{ }^{2-}\right)$ was determined by USEPA method 9038 (USEPA, 1997). Ten (10) $\mathrm{g}$ of a sample was placed into a $100 \mathrm{~mL}$ HDPE bottle, $50 \mathrm{~mL}$ of $24^{\circ} \mathrm{C}$ distilled water was added and agitated for 60 minutes to dissolve $\mathrm{SO}_{4}{ }^{2-}$ ions, then allowed to settle, followed by filtration through Whatman ${ }^{\mathrm{TM}} 42$ filter paper. The $\mathrm{SO}_{4}{ }^{2-}$ ion was precipitated (with barium-chloride $\left[\mathrm{BaCl}_{2}\right]$ to barium-sulfate $\left(\mathrm{BaSO}_{4}\right)$ forming a suspension under controlled conditions to determine the concentration using a nephelometer and a calibration curve for sulfate (USEPA, 1997). Sample weight and solution volume were accounted in the data.

Sediment chloride was determined potentiometrically using a chloride ion $\left(\mathrm{Cl}^{-}\right)$selective electrode (ISE) in conjunction with a chloride combination ISE on a pH meter with an expanded millivolt scale. Each sample was determined by measuring $\sim 10 \mathrm{~g}$ into a $100 \mathrm{ml}$ HDPE bottle, adding $50 \mathrm{ml}$ of $24^{\circ} \mathrm{C}$ distilled water and agitated for 60 minutes to dissolve $\mathrm{Cl}^{-}$ions. Once the sediment was agitated, the solution was filtered through a Whatman ${ }^{\mathrm{TM}}$ 42 filter paper. Each sample was compared to a calibration curve with final concentration determined by accounting for sample weight and solution volume.

Calcium carbonate $\left(\mathrm{CaCO}_{3}\right)$ was measured by gravimetric techniques outlined by Bauer et al. (1972). One (1) g of sediment was measured into a tared $25 \mathrm{~mL}$ beaker to the nearest $0.001 \mathrm{~g}$. Ten (10) $\mathrm{mL}$ of $5 \mathrm{~N}$ hydrochloric acid $(\mathrm{HCl})$ were added to the beaker covered with a watch glass to prevent splashing. The sample was swirled twice at 10 minute intervals for 30 minutes to allow the $\mathrm{HCl}$ and sediment reaction to dissolve all available carbonates. Samples were placed into an oven for 12 hours at $105^{\circ} \mathrm{C}$, removed and allowed to cool before the weight was recorded on both the beaker and the sediment. The difference between the original beaker and sediment weight and the final weight, after the $\mathrm{HCl}$ addition, was recorded as $\mathrm{mg} \mathrm{kg}^{-1} \mathrm{CaCO}_{3}$.

$4.5 \mathrm{Mg} / \mathrm{Ca}$ ratios, ${ }^{14} \mathrm{C}, \delta^{13} \mathrm{C}$ and $\delta^{18} \mathrm{O}$

$\mathrm{Mg} / \mathrm{Ca}$ ratios were used to examine possible links between past environments and associated temperatures. Magnesium is incorporated into calcite deposited in sediments upon evaporation of water. With the incorporation of $\mathrm{Mg}$ as an impurity in calcite (i.e. endothermic), more is incorporated into growing crystals at higher temperatures (Morse et al., 1997). Mg is a divalent cation that substitutes for Ca during the development of biogenic calcium-carbonate (Barker et al., 2005; Barker et al., 2003). When Mg is incorporated into calcite, its incorporation is influenced by the temperature of the surrounding water; increasing with rising temperatures (Ries, 2004; Barker et al., 2005).

Korber et al. (2007), Morse et al. (1997), and Sun et al. (2015) suggest $\mathrm{Mg} / \mathrm{Ca}$ ratios $>3.5$ represent modern freshwater. Higher atmospheric temperatures will produce higher $\mathrm{Mg} / \mathrm{Ca}$ ratios from the aquatic chemical system, whereas lower atmospheric temperatures will produce lower $\mathrm{Mg} / \mathrm{Ca}$ ratios from the same aquatic chemical system (Barker et al., 2005; Cleroux et al., 2008; Regenberg et al., 2009). For this study, ratios $<2.0$ represent a cooler period with decreased evaporation; ratios $>3.5$ represent higher temperatures with increased evaporation.

All ${ }^{14} \mathrm{C}$ samples were performed by Beta Analytic Inc. in Miami, Florida and the University of Arizona Accelerator Mass Spectrometry Laboratory in Tucson, Arizona. Beta Analytic Inc. and the University of Arizona Accelerator Mass Spectrometry Laboratory data are conveyed as Conventional Radiocarbon Age (CRA) reported in ${ }^{14} \mathrm{C}$ and cal yrs BP $\left(2 \sigma\right.$ age range). Samples for ${ }^{14} \mathrm{C}$ dating were composed of one bulk sample (charcoal 
present) and four grab samples (detrital carbon). The bulk sample was $\sim 10 \mathrm{~kg}$ collected from within a subsurface beach zone (LU3) layer that was floated for visible charcoal and sent to the laboratory for analysis. The four grab samples came from single locations of $\sim 300 \mathrm{~g}$ of sediment collected at each location from within the excavation (LGL5), and sent for analysis.

Laboratory procedures for ${ }^{14} \mathrm{C}$ analysis first visually inspected samples for size, homogeneity, debris, inclusions, clasts, grain size, organic constituents and potential contaminants. Their first step was to disperse sediment samples in de-ionized water, homogenized through stirring and sonication, then sieved through a $180 \mu \mathrm{m}$ sieve with materials passing through the sieve used for the analysis. The next step in preparation was soaking samples in $2.5 \mathrm{~N} \mathrm{HCl}$ at $90^{\circ} \mathrm{C}$ for a minimum of 1.5 hours to ensure removal of carbonates (inorganics) so that a measure of organic carbon could be achieved. Following the $\mathrm{HCl}$ at $90^{\circ} \mathrm{C}$, serial rinses with $70^{\circ} \mathrm{C}$ de-ionized water were performed until neutrality was reached. Any debris (i.e. micro-rootlets) was discarded during rinsing. Samples were then dried in an oven at $100^{\circ} \mathrm{C}$ for $12-24$ hours and then concentrated $\mathrm{HCl}$ was applied to a representative sub-sample under magnification to confirm the absence of carbonates. If carbonate was still present, the laboratory would repeat the HCL processes to remove any inorganic carbonates from the sample. As a final point, although the use of ${ }^{14} \mathrm{C}$ dating does present possible erroneous results, though slight, it is the standard used by researchers for bulk dating of detrital carbon in dry lake sediments, even if no visual carbon is present (i.e. Enzel et al., 2003; Negrini et al., 2006; Quade et al., 2003; Wells et al., 2003).

The University of Arizona Environmental Isotope Laboratory, Department of Geosciences analyzed sediment samples for $\delta^{13} \mathrm{C}$ and $\delta^{18} \mathrm{O}$ in mineral carbonates. Values for $\delta^{13} \mathrm{C}$ are important for their understanding of past environments; an increase in prime productivity causes a corresponding rise in $\delta{ }^{13} \mathrm{C}$ as supplementary ${ }^{12} \mathrm{C}$ is locked up in plants. When organic carbon is buried, more ${ }^{12} \mathrm{C}$ is locked out of the sediment system than is found in background systems. Samples analyzed for $\delta^{18} \mathrm{O}$ ratios were used to indirectly determine the temperature of the surrounding water at the time the sediment was deposited. When $\delta^{18} \mathrm{O}$ ratios vary slightly, it is a response to temperature of the surrounding water. Other factors related to $\delta^{18} \mathrm{O}$ are salinity and volume of water in a given area. Studies have used this technique on gastropods, endocarps, and other carbonate matrices; this study used $\delta^{18} \mathrm{O}$ and $\delta{ }^{13} \mathrm{C}$ to detect chemical anomalies.

\subsection{Quality Control/Quality Assurance}

Quality assurance/quality control protocols followed USEPA methods (USEPA, 1997). All analyses required replicated certified reference material purchased from a USEPA certified supplier. Instrument detection limits (IDL) were calculated by multiplying the standard deviation (SD) of a fortified reagent blank by three times. Statistical data were calculated excluding values that were below IDL values. Sample quality control was processed per protocols as outlined in USEPA SW-846 procedures (USEPA, 1997). Finally, all samples were analyzed in triplicate following USEPA requirements for relative percent deviation (RPD) of $<20 \%$ to be acceptable (USEPA, 1997).

\subsection{Stratigraphy and Chronologic Context}

Chemical proxy data ("the anomaly") were compared to this local stratigraphy as well as broader geomorphic features identified along the LGL transect for selection of a point for further excavation. To document the stratigraphy contributing to the anomalies in initial chemical proxy data, a larger $(1.5 \mathrm{~m} \mathrm{x} 1.5 \mathrm{~m}$ wide) test pit was excavated at LGL 5 (Fig. 3B). Strata were exposed in this excavation on two vertical walls with north-south and east-west axes to a depth of $1.96 \mathrm{~m}$, sketched and photographed. Samples for isotopic analyses were collected from different strata, taking care to avoid sampling across stratigraphic discontinuities. Sediment from identified layers were sieved for gradation and recorded. Water depth is expressed in $\mathrm{m}$, and changes with difference in depth $\left(\Delta_{\mathrm{w}}\right)$ from the current Ivanpah playa floor of $\sim 794 \mathrm{~m}$ amsl. For this study, Rehies et al. (2012) definition was applied for "shallow" lake depths of less than $5 \mathrm{~m}\left(\Delta_{\mathrm{w}} \leq 5 \mathrm{~m}\right)$, "moderate" depth to $\Delta_{\mathrm{w}}$ of 5-8 $\mathrm{m}$, and "deep" lake conditions of $\Delta_{\mathrm{W}}>8 \mathrm{~m}$. For the purpose of this paper, the end of the Pleistocene is placed at $12,000 \mathrm{yrs} \mathrm{BP}$, the early to middle Holocene boundary at 7,800 yrs BP, and the beginning of the late Holocene at 4,000 yrs BP.

\section{Results}

\subsection{Sediment Chemical Proxy Anomaly}

Coring was used only for the identification of subsurface anomalies so that a location could be identified for further excavation. Elevation change at Ivanpah is $\sim 12.7 \mathrm{~m}$ from LGL $1(794.4 \mathrm{~m})$, at the playa base surface, to $807.1 \mathrm{~m}$ amsl at LGL 12: the Lucy Grey bajada creosote bush scrub transition zone (Fig 2b). Table 1 shows a distinct anomaly in data with $\mathrm{Al}, \mathrm{Fe}, \mathrm{K}$, and $\mathrm{V}$ following a uniform distribution below the surface across LGL 1 
through 12, as did other constituents such as metals, $\mathrm{SO}_{4}{ }^{2-}, \mathrm{Cl}^{-}, \mathrm{pH}, \mathrm{CaCO}_{3}$ (see supplementary tables). Aluminum, $\mathrm{Fe}, \mathrm{K}$, and $\mathrm{V}$ are higher within the horizontally positioned ("bedded ") anomaly and bracketed by lower concentrations above and below the max concentrations (Table 1; highlighted in grey and lighter grey) based on $\pm 1 \sigma$. Data shows Al, Fe, K and V have similar distributions at approximately -20 to $-40 \mathrm{~cm}$ bgs at LGL 1 through LGL 6, surfacing at LGL 7 (799.7 m), descending to $20-40 \mathrm{~cm}$ bgs by LGL 8, surfacing again at LGL $11(804.2 \mathrm{~m})$ and descending to $20-40 \mathrm{~cm}$ bgs at LGL 12 . Largely, this anomaly is positioned bgs with a uniform depth except at LGL 7 and LGL 11, where it surfaces.

Crustal (e.g. $\mathrm{Al}, \mathrm{Fe}, \mathrm{Ca}$ ) and trace metals (e.g. $\mathrm{Cr}, \mathrm{Cu}, \mathrm{Pb}, \mathrm{V}$ ) ranged between 3,500 and $46,010 \mathrm{mg} \mathrm{kg}^{-1} \mathrm{Al} ; 5,150$ and $29,780 \mathrm{mg} \mathrm{kg}^{-1} \mathrm{Fe}$; and 8.7 and $83 \mathrm{mg} \mathrm{kg}^{-1} \mathrm{~V}$ across the LGL transect (see supplementary tables). These findings are not unusual as oxidizing environments increase the presence of $\mathrm{FeOOH}$ in horizontally bedded sediments (Stumm and Morgan, 1996; Sanchi et al., 2015), providing adsorptive capacity for charged species dissolved in surface and percolating waters. Data presented in Table 1, including supplementary tables, shows $\mathrm{Al}$, $\mathrm{Fe}, \mathrm{Zn}$ and other metals (e.g. As, $\mathrm{Ba}, \mathrm{Ca}, \mathrm{Cr}$. Cu, $\mathrm{Li}, \mathrm{K}, \mathrm{Mg}, \mathrm{Mn}, \mathrm{Ni}, \mathrm{Pb}, \mathrm{Ti}, \mathrm{V}$ ) tend to follow this horizontal bedding ("an anomaly") at depth ( $\sim 20-40 \mathrm{~cm})$ from LGL 1 out $\sim 4.5 \mathrm{~km}$ east to LGL 12.

Sediment $\mathrm{pH}$ also measured along the LGL transect ranged between 6.81 and 8.50 standard units (SU) with a distribution comparable to metals and other chemical proxies (Table 2). Core sample $\mathrm{pH}$, although not significantly different across the LGL transect, shows the anomaly at depth and followed metal accumulations presented in Table 1, a common association know between $\mathrm{pH}$ and metals (Tardy and Roquin, 1992; Watanabe et al., 2001). These findings are not unusual as sediment $\mathrm{pH}$ will support similar chemistries in horizontal beds where there are analogous redox conditions (Tardy and Roquin, 1992).

Data for $\delta^{13} \mathrm{C}$ and $\delta^{18} \mathrm{O}$ were also used to identify patterns below the surface with two locations (LGL 3 and 5; Fig. 3B) along the LGL transect selected for measurements. Table 3 displays $\delta^{13} \mathrm{C}$ and $\delta^{18} \mathrm{O}$ with comparable alignments as presented in Tables 1 and 2. LGL 3 is located within the playa (794.5 m amsl) base surface, whereas LGL 5 is located on the Lucy Grey bajada (796.4 m amsl) $\sim 1.9 \mathrm{~m}$ above LGL 3. Data for $\delta^{13} \mathrm{C}$ and $\delta^{18} \mathrm{O}$ at LGL 3 and 5 have a similar orientation, although with minor differences; $-2.20,-2.56 \delta^{13} \mathrm{C}$ and $-4.71,-5.10 \%$ $\delta^{18} \mathrm{O}$, respectively.

Table 1. Selected chemical proxies for locations $1-12$ of the LGL transect with Max $\pm 1 \sigma$ ranges

\begin{tabular}{|c|c|c|c|c|c|c|c|c|c|c|c|c|c|}
\hline \multirow{2}{*}{\multicolumn{2}{|c|}{$\begin{array}{c}\text { Location } \\
\text { Elevation }\end{array}$}} & 1 & 2 & 3 & 4 & 5 & 6 & 7 & 8 & 9 & 10 & 11 & 12 \\
\hline & & 794.4 & 794.7 & 794.5 & 796.3 & 796.4 & 797.4 & 799.7 & 800.6 & 801.9 & 803.2 & 804.2 & 807.1 \\
\hline \multicolumn{2}{|c|}{\begin{tabular}{l|l} 
Depth \\
\end{tabular}} & & & & & & & & & & & & \\
\hline \multirow{6}{*}{$\mathrm{Al}$} & 10 & 11,600 & 12,500 & 16,500 & 18,750 & 28,860 & 27,850 & 33,160 & 4,015 & 36,920 & 6,700 & 44,580 & 31,200 \\
\hline & 20 & 20,550 & 21,000 & 17,000 & 16,600 & 36,290 & 41,920 & 44,760 & 7,200 & 38,670 & 3,500 & 43,010 & 45,920 \\
\hline & 30 & 20,600 & 20,300 & 24,800 & 19,500 & 49,670 & 40,010 & 44,750 & 9,350 & 41070 & 7,650 & 41,920 & 46,010 \\
\hline & 40 & 20,900 & 23,500 & 24,100 & 17,100 & 39,370 & 32,550 & 34,760 & 8,200 & 40,960 & 7,360 & 36,410 & 33,010 \\
\hline & 50 & 20,400 & 21,050 & 20,800 & 16,200 & 32,220 & 35,600 & 26,130 & 5,800 & 36,000 & 6,080 & 31,440 & 32,000 \\
\hline & STDV & 4035 & 4188 & 3863 & 1426 & 7990 & 5674 & 8028 & 2081 & 2301 & 1657 & 5443 & 7638 \\
\hline \multicolumn{2}{|c|}{$\operatorname{Max}+1 \boldsymbol{\sigma}$} & 24935 & 27688 & 28663 & 20926 & 57660 & 47594 & 52788 & 11431 & 43371 & 9307 & 50023 & 53648 \\
\hline \multicolumn{2}{|c|}{ Max $-1 \sigma$} & 16865 & 19312 & 20937 & 18074 & 31380 & 36246 & 36732 & 7269 & 38769 & 5993 & 39137 & 38372 \\
\hline \multirow{6}{*}{$\mathrm{Fe}$} & 10 & 17200 & 15560 & 15700 & 9050 & 23340 & 21810 & 25920 & 5150 & 24800 & 8100 & 29000 & 23400 \\
\hline & 20 & 17350 & 16265 & 16805 & 13350 & 25020 & 27250 & 27190 & 8305 & 25800 & 8950 & 29100 & 28630 \\
\hline & 30 & 16550 & 24550 & 26400 & 24800 & 29780 & 26600 & 27450 & 18250 & 26210 & 9250 & 28700 & 29110 \\
\hline & 40 & 27650 & 27800 & 26900 & 25900 & 26690 & 21880 & 24080 & 29750 & 25830 & 7800 & 25600 & 23000 \\
\hline & 50 & 27500 & 26350 & 26500 & 17750 & 25050 & 24680 & 21760 & 16800 & 24270 & 7900 & 23300 & 22800 \\
\hline & STDV & 5782 & 5774 & 5684 & 7251 & 2434 & 2554 & 2377 & 9632 & 812 & 657 & 2591 & 3190 \\
\hline \multicolumn{2}{|c|}{$\operatorname{Max}+1 \boldsymbol{\sigma}$} & 33432 & 33574 & 32584 & 33151 & 32214 & 29804 & 29827 & 39382 & 27022 & 9907 & 31691 & 32300 \\
\hline \multicolumn{2}{|c|}{$\operatorname{Max}-1 \sigma$} & 21868 & 22026 & 21216 & 18649 & 24256 & 24696 & 25073 & 20118 & 25398 & 8593 & 26509 & 25920 \\
\hline \multirow{7}{*}{ K } & 10 & 22270 & 27820 & 26790 & 10150 & 8815 & 8280 & 9581 & 1920 & 9144 & 9250 & 9513 & 8065 \\
\hline & 20 & 22405 & 30330 & 29300 & 17705 & 9734 & 9576 & 9611 & 2614 & 9753 & 9575 & 9404 & 9439 \\
\hline & 30 & 29480 & 25040 & 28000 & 21395 & 9620 & 9600 & 9784 & 2831 & 9461 & 16200 & 9564 & 9217 \\
\hline & 40 & 32890 & 34050 & 28650 & 24980 & 9532 & 8635 & 9341 & 2214 & 9312 & 10800 & 9093 & 8900 \\
\hline & 50 & 30380 & 31670 & 27390 & 20150 & 9070 & 8556 & 7913 & 2402 & 9448 & 8800 & 1280 & 8850 \\
\hline & STDV & 4863 & 3479 & 993 & 5539 & 393 & 616 & 762 & 352 & 224 & 3041 & 3633 & 522 \\
\hline & $\operatorname{Max}+1 \boldsymbol{\sigma}$ & 37753 & 37529 & 30293 & 30519 & 10127 & 10216 & 10546 & 3183 & 9977 & 19241 & 13197 & 9961 \\
\hline
\end{tabular}




\begin{tabular}{|c|c|c|c|c|c|c|c|c|c|c|c|c|c|}
\hline \multicolumn{2}{|c|}{$\operatorname{Max}-1 \sigma$} & 28027 & 30571 & 28307 & 19441 & 9341 & 8984 & 9022 & 2479 & 9529 & 13159 & 5931 & 8917 \\
\hline \multirow{8}{*}{$\begin{array}{l}\mathrm{M} \\
\mathrm{N}\end{array}$} & 10 & 46 & 39 & 39 & 16 & 55 & 46 & 65 & 8.7 & 51 & 12 & 79 & 57 \\
\hline & 20 & 44 & 37 & 37 & 28 & 57 & 65 & 71 & 14 & 69 & 15 & 83 & 78 \\
\hline & 30 & 48 & 42 & 41 & 34 & 77 & 61 & 71 & 19 & 67 & 16 & 82 & 78 \\
\hline & 40 & 48 & 44 & 43 & 41 & 67 & 49 & 62 & 18 & 61 & 11 & 68 & 69 \\
\hline & 50 & 44 & 45 & 40 & 31 & 61 & 43 & 58 & 13 & 63 & 14 & 57 & 66 \\
\hline & STDV & 2.0 & 3.4 & 2.2 & 9.2 & 8.9 & 9.7 & 5.7 & 4.1 & 7.0 & 2.1 & 11.1 & 8.8 \\
\hline & $x+1 \sigma$ & 50 & 48 & 45 & 50 & 86 & 75 & 77 & 23 & 76 & 18 & 94 & 87 \\
\hline & $x-1 \sigma$ & 46 & 42 & 41 & 32 & 68 & 55 & 65 & 15 & 62 & 14 & 72 & 69 \\
\hline
\end{tabular}

Note: Dark shading is maximum value in vertical profile; lighter shading is $\pm 1 \sigma$ of maximum value detected in vertical profile; elevation in meter; depth in $\mathrm{cm}$ below surface; concentrations in $\mathrm{mg} \mathrm{kg}^{-1}$; $\sigma$ is standard deviation. Additional data available in supplementary tables.

Table 2. Selected $\mathrm{pH}$ values found in the Lucy Grey Line

\begin{tabular}{lllll}
\hline \multicolumn{5}{l}{ LGL Locations } \\
\hline Depth & 3 & 5 & 7 & 11 \\
10 & 7.21 & 7.39 & 7.62 & 7.31 \\
20 & 7.41 & 7.30 & 7.63 & 7.27 \\
30 & 7.54 & 7.62 & 7.27 & 7.19 \\
40 & 8.05 & 7.15 & 7.16 & 7.22 \\
50 & 7.96 & 7.81 & 7.34 & 7.54 \\
\hline
\end{tabular}

Note: $\mathrm{pH}$ values are in S.U.; depth in $\mathrm{cm}$ below surface; shaded values match Table 1

The lowest $\delta^{13} \mathrm{C}$ and $\delta^{18} \mathrm{O}$ values detected at LGL $3(-2.56 \%$, $-5.42 \%$, respectively) were at $0-10 \mathrm{~cm}$ bgs. LGL $5 \delta{ }^{13} \mathrm{C}$ and $\delta^{18} \mathrm{O}$ revealed a comparable pattern to LGL $3 ; \delta^{13} \mathrm{C}$ ranged between $1.39 \%$ and $-1.33 \%$ with $1.39 \%$ at $50 \mathrm{~cm}$ bgs and $-1.33 \%$ at $0-10 \mathrm{~cm}$ bgs. This alignment shows the highest $\delta{ }^{13} \mathrm{C}$ at $40-50 \mathrm{~cm}$ bgs with the lowest values at $0-10 \mathrm{~cm}$ bgs. Distribution of $\delta^{13} \mathrm{C}$ and $\delta^{18} \mathrm{O}$ align with other chemical proxies with a distinct change $(\boldsymbol{\Delta})$ in values based on depth. The $\Delta_{\delta}{ }^{18} \mathrm{O}$ is similar to $\Delta_{\delta}^{13} \mathrm{C}$; highest at $40-50 \mathrm{~cm}$ bgs with the lowest values detected at $0-10 \mathrm{~cm}$ bgs. Data for both $\delta{ }^{13} \mathrm{C}$ and $\delta{ }^{18} \mathrm{O}$ illustrate a similar anomaly below the surface as seen with other constituents. The observed pattern is consistent when the local system is under similar hydrologic balances caused by environmental changes (e.g. Watanabe et al., 2001, Regenberg et al., 2009). Data also show the highest $\delta{ }^{13} \mathrm{C}$ value (1.39\%) at LGL 5 at $40-50 \mathrm{~cm}$ bgs with the lowest value $(-1.33 \%$ ) at $0-10 \mathrm{~cm}$ bgs. At shallower depths $(0-10 \mathrm{~cm}), \Delta_{\delta}{ }^{13} \mathrm{C}$ decreases, likely the result of increased temperatures over the past 1.0 ka yrs BP. Moreover, $\delta{ }^{13} \mathrm{C}$ data indicate that the deeper levels $(40-50 \mathrm{~cm}$ bgs) were likely long-standing, water-rich environments. LGL $5 \delta{ }^{18} \mathrm{O}$ values were highest (-2.85 and $-5.30 \%$, respectively) at $40-50 \mathrm{~cm}$ and $20-30 \mathrm{~cm}$ bgs with the lowest (-5.66 and $-5.42 \%$, respectively) at $0-10 \mathrm{~cm}$ bgs. Data show $\delta^{13} \mathrm{C}$ and $\delta^{18} \mathrm{O}$ within the LGL5 anomaly are consistent with mid-Holocene. The $\delta{ }^{13} \mathrm{C}$ data ranged from -0.11 to $0.03 \%$ and $\delta{ }^{18} \mathrm{O}$ data ranged from -3.56 to- $2.85 \%$.

Table 3. $\delta^{18} \mathrm{O}$ and $\delta{ }^{13} \mathrm{C}$ ratios for LGL 3 and 5

\begin{tabular}{llllll}
\hline Location & depth & $\delta^{13} \mathrm{C}$ & $\mathrm{STDV}$ & $\delta^{18} \mathrm{O}$ & $\mathrm{STDV}$ \\
\hline \multirow{4}{*}{3} & 10 & -2.56 & 0.036 & -5.42 & 0.022 \\
& 20 & -2.21 & 0.012 & -5.10 & 0.037 \\
& 30 & -2.48 & 0.020 & -4.71 & 0.062 \\
& 40 & -2.20 & 0.017 & -5.34 & 0.021 \\
& 50 & -2.30 & 0.005 & -5.30 & 0.034 \\
5 & 0 & -1.33 & 0.024 & -5.66 & 0.029 \\
& 20 & -1.33 & 0.025 & -4.92 & 0.035 \\
& 30 & -0.11 & 0.031 & -3.56 & 0.045 \\
& 40 & 0.03 & 0.011 & -4.23 & 0.018 \\
& 50 & 1.39 & 0.017 & -2.85 & 0.072 \\
\hline
\end{tabular}

Note: Depth: cm below surface, values are in \%o; Laboratory ID: AA K883 
Metal ratios $(\mathrm{Mg} / \mathrm{Ca})$ shown in Table 4 have comparable alignments to other sediment chemistry presented in Tables 1-3; following the detected anomaly. Data show $81 \%$ of $\mathrm{Mg} / \mathrm{Ca}$ ratios are $<3.5$ and $21 \%$ are $>3.5$; values set by other authors to indicate higher temperatures and increased evaporation (Barker et al., 2005; Cleroux et al., 2008; Regenberg et al., 2009). Only $5 \%$ of ratios are $<2.0$; a value symptomatic of cooler temperatures with decreased evaporation (Barker et al., 2005; Regenberg et al., 2009). Data for LGL 3: 30-50 cm; LGL 5: 20-40 cm; and LGL 7 and 11: 0-20 cm, show elevated $\mathrm{Mg} / \mathrm{Ca}$ ratios within the anomaly, indicative of long-standing water. Table 4 displays a comparable pattern as shown in other data tables; lowest $\mathrm{Mg} / \mathrm{Ca}$ ratios are situated within the identified chemical-proxies. These findings show that Ivanpah had periods of moist-humid conditions followed by aridity caused by environmental fluctuations.

Table 4. $\mathrm{Mg} / \mathrm{Ca}$ ratios of the $\mathrm{LGL}$ transect

\begin{tabular}{lllllllllllll}
\hline \multicolumn{10}{c}{ Locations } & \multicolumn{11}{c}{1} \\
\hline Depth* & 1 & 2 & 3 & 4 & 5 & 6 & 7 & 8 & 9 & 10 & 11 & 12 \\
10 & 3.83 & 3.64 & 4.03 & 2.07 & 2.89 & 2.45 & 2.44 & 2.54 & 2.32 & 2.08 & 2.85 & 1.97 \\
20 & 3.89 & 3.94 & 3.86 & 2.83 & 2.48 & 2.99 & 2.36 & 2.30 & 2.35 & 2.03 & 2.95 & 2.29 \\
30 & 3.94 & 4.32 & 3.19 & 2.73 & 3.38 & 3.12 & 2.31 & 2.08 & 2.82 & 2.24 & 2.62 & 2.31 \\
40 & 3.16 & 4.21 & 3.60 & 1.86 & 3.29 & 2.61 & 2.29 & 2.83 & 2.80 & 2.09 & 2.61 & 2.41 \\
50 & 3.72 & 4.38 & 3.60 & 1.82 & 2.99 & 2.79 & 2.31 & 2.72 & 2.99 & 2.13 & 2.49 & 2.47 \\
\hline
\end{tabular}

Note: $*$ cm below surface

\subsection{Geomorphic and Stratigraphic Features at LGL-Test Pit 5 Discussion}

Chemical proxies (shallow coring) led to a $1.5 \times 1.5 \mathrm{~m}$ wide by $\sim 2 \mathrm{~m}$ depth excavation at LGL 5 (796.4 m amsl; $35.523617^{\circ},-115.341933^{\circ}$ ) to explore the anomaly identified at $20-40 \mathrm{~cm}$ bgs (Table 1, Fig. 4A). Research shows the presence of possible lacustrine units below the surface; these units are designated as Lake Unit (LU) 0 , 1,2 and 3 with LU3 subdivided into LU3a, b, c, and d. Five samples were collected from LGL 5 and sent for ${ }^{14} \mathrm{C}$ analysis and are presented within their respective sections below. The excavation sidewalls displayed a mixture of compositions dominated by sand, silt, and clay, with some clastic materials at shallow depths, unconformities indicative of three possible lake beds, and two apparent playa surfaces exhibiting mud cracks.

The surface (unit ALØ) of LGL5 is composed of a relatively thin $(\sim 10 \mathrm{~cm}$ bgs) layer of light brown (Color hue 7.5YR 6/4), very fine to fine sandy loam with granules, pebbles and small gravels at the base (Fig. 4F). ALØ is dominated by an upward sequence of fine-earth textures and a non-laminated matrix, aeolian in origin, becoming coarser at depth, grading to pea-sized pebbles, clasts, and small gravels situated on a boundary surface (LU3d) at depth $(-10 \mathrm{~cm})$. ALØ represents a late Holocene-to-modern deposit situated on an older unit (LU3).

LU3 is a relatively thick unit (LU3a, b, c, d) ranging from $\sim 10$ to $60 \mathrm{~cm}$ bgs with a base elevation of $795.8 \mathrm{~m}$ amsl when adjusted for ground elevation. Materials within LU3d ( $\sim 10$ to $20 \mathrm{~cm} \mathrm{bgs)}$ is an aridisol composed of light brown to reddish brown, sandy loam (color hue 7.5YR 6/4) with subrounded to subangular texture, showing classic oxidation (Fig. 4B; Retallack, 1988). This unit contains 19.4\% pea-sized gravels $(0.5-1.0 \mathrm{~cm}), 72.9 \%$ sands, and $8.0 \%$ silts (Table 5), consolidated by clays with carbonate strings forming a weak vesicular surface that appears erosionally truncated. The surface of LU3d displays a disconformity (truncated) representing a rapid regressive phase overlain by AlØ and leaving no subsequent visual evidence. The lack of well-developed soils in LU3d is consistent with a younger age for the most recent transgressional phase situated on a base of gravels and sands of LU3a, b, and c. Lastly, LU3d deposition is difficult to determine, the structure reduces vertical infiltration, making it problematic to date owing to very high inorganic carbon, though it reflects the cumulative effects of pedogenic processes with time.

LU3a, b, and c consist of $27.5 \%$ gravels, $71.4 \%$ sands and $1.1 \%$ silts, sedimentologically characteristic of a fluvial deposit beach facies containing a poorly sorted matrix (Table 5; Figs. 4). The unit grades upward from sub-rounded basal gravels $(\sim 2-5 \mathrm{~cm})$ and clasts $(\sim 2-5 \mathrm{~cm})$ with minor sand in LU3a (Fig. 4C); pea-sized beach gravels $(\sim 0.7-2 \mathrm{~cm})$ in LU3b (Fig. 4F); and sand/loamy sand in LU3c (Fig. F) yielding a composite (LU3a, b, c) age of 1,050-1,025 cal yrs BP (Table 6). All subunits within LU3 (a-c) are light brown with a color hue 7.5YR 6/3. The uppermost portion of LU3c is positioned at $796.2 \mathrm{~m}$ amsl when adjusted for current surface elevation. Evidence shows that a shoreline advanced eastward from changing lake volumes, water deepened at LGL 5, depositing sandy loam with pea-sized beach gravels within unit LU3a-c forming a classic transgressional sequence of poorly sorted, lacustrine gravel beach facies (Bacon et al., 2006). Structurally, LU3 (a-c) is $\sim 30 \mathrm{~cm}$ 
thick fluvial deposit of sands, pea-sized gravels and clasts, all positioned on an older lacustrine unit boundary surface (LU2).

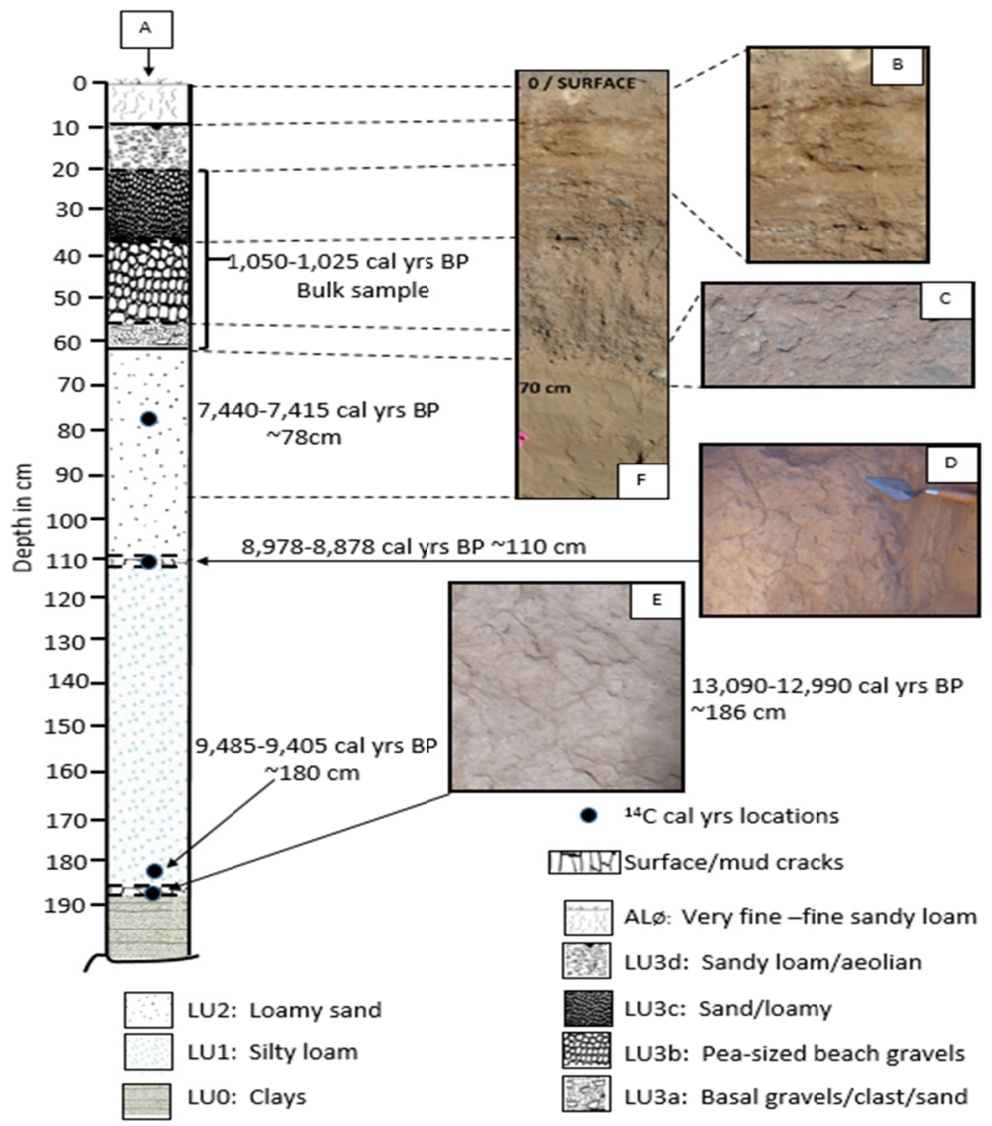

Figure 4. LGL 5 stratigraphic cross section from transect

Unit LU2 is positioned at $795.8 \mathrm{~m}$ amsl when adjusted for elevation and consists of $<0.1 \%$ gravels, $89.1 \%$ sands and $10.4 \%$ silts and $<0.5 \%$ clays (Table 5). This unit consist of a light brown loamy sand (color hue 7.5YR 6/4) containing carbonate strings within the upper few $(\sim 3) \mathrm{cm}$ of a thicker component ranging from $\sim 63 \mathrm{~cm}$ to $\sim 109$ $\mathrm{cm}$ bgs yeilding a date of 7,440-7,415 cal yrs BP at $\sim 78 \mathrm{~cm}$ bgs (Table 6 ). Under magnification (4x), bedding in LU2 consists of loamy sand-sized grains arranged in parallel lines (partings and intervening) with fine to very fine sands erosionally truncated at $\sim 63 \mathrm{~cm}$ bgs (Fig. 4F) exhibiting minor surface cracking. LU2 sediments are very well sorted and interbedded, with very thin (i.e. 1-3 cm thick) lamination throughout, interpreted as beach sand overlain by a coarser fluvial unit LU3 as described by McKee and Weir (1953). LU2 is likely the result of a low energy suspension event overlain LU1.

Table 5. Grain size, color hue of LGL5 sediments

\begin{tabular}{ccccccc}
\hline Unit ID & $\begin{array}{c}\sim \text { Depth } \\
(\mathbf{c m})\end{array}$ & Color hue & Gravel \% & Sand \% & Silt \% & Clay\% \\
\hline ALO & $0-10$ & 7.5 YR 6/4 & 1.0 & 83.4 & 15.5 & $<0.1$ \\
LU3d & $10-21$ & 7.5 YR 6/4 & 19.4 & 72.9 & 8.0 & $<0.1$ \\
LU3c & $21-36$ & 7.5 YR 6/3 & 20.8 & 74.1 & 5.1 & $<0.1$ \\
LU3b & $36-55$ & 7.5 YR 6/3 & 23.7 & 74.8 & 1.8 & $<0.1$ \\
LU3a & $55-63$ & 7.5 YR 6/3 & 37.6 & 62.3 & 0.1 & $<0.1$ \\
LU2 & $63-109$ & 7.5 YR 6/4 & $<0.1$ & 89.3 & 10.5 & $<0.1$ \\
LU1 & $109-186$ & 7.5 YR 7/3 & $<0.1$ & 25.7 & 74.2 & $<0.1$ \\
LU0 & 186 -unknown & 7.5 YR 6/4 & $<0.1$ & 44.2 & 53.1 & 2.6 \\
\hline
\end{tabular}

Note: LU0 was explored only to $196 \mathrm{~cm}$ below surface 
Table 6. Radiocarbon dates from LGL5 sediments

\begin{tabular}{|c|c|c|c|c|c|c|}
\hline Lab ID & Unit ID & $\begin{array}{l}\text { Depth }^{1} \\
(\mathrm{~cm})\end{array}$ & Materials dated & $\delta^{13} \mathrm{C}(\%)$ & $\begin{array}{l}{ }^{14} \mathrm{C}_{\text {age }^{2}} \\
\text { (yrs BP) }\end{array}$ & $\begin{array}{l}\text { cal yrs } \mathrm{BP}^{3} \\
(2 \sigma \text { age range ) }\end{array}$ \\
\hline Beta432398 & LU3(a-c) & -30 to -61 & Bulk $C_{\text {org }}$ & -11.5 & $1,060 \pm 30$ & $1,050-1,025$ \\
\hline Beta434682 & LU2 & -78 & Grab $\mathrm{MC}_{\text {org }}$ & -17.5 & $6,500 \pm 31$ & $7,440-7,415$ \\
\hline AA107397 & LU1 & -110 & Grab $\mathrm{MC}_{\text {org }}$ & -18.1 & $7,940 \pm 31$ & $8,978-8,878$ \\
\hline Beta434906 & LU1 & -180 & Grab $\mathrm{MC}_{\text {org }}$ & -21.6 & $8,400 \pm 30$ & $9,485-9,405$ \\
\hline Beta436547 & LU0 & -186 & Grab $\mathrm{MC}_{\text {org }}$ & -17.0 & $11,160 \pm 40$ & $13,090-12,990$ \\
\hline
\end{tabular}

Note: C: carbon, M: microscopic, org: organic, ${ }^{1} \mathrm{~cm}$ below surface; ${ }^{2}$ reported in conventional radiocarbon years; ${ }^{3}$ reported in calibrated years BP with $95 \%$ probability

LU1 is a well preserved lacustrine unit commencement at $\sim 110 \mathrm{~cm} \mathrm{bgs,} \mathrm{extending} \mathrm{to} \sim 186 \mathrm{~cm}$ bgs, and appearing to have been deposited by low energy suspension. The superficial portion of this unit dated to $8,978-8,878$ cal yrs BP at $\sim 110 \mathrm{~cm}$ bgs and at depth $(\sim 180 \mathrm{~cm} \mathrm{bgs})$ dated $9,485-9,405$ cal yrs BP. The surface of LU1 $(\sim 110 \mathrm{~cm})$ is desiccated, showing signs of cracking ("mud-cracks") with a crust rich in swelling clays exhibiting evaporite-staining of the surface $(\sim 2 \mathrm{~cm})$, indicative of an established desert playa (Fig. 4D). The sediment matrix consists of very thin laminated pink silt loam (color hue $7.5 \mathrm{YR} 7 / 3$ ) containing $<0.4 \%$ gravels, $24.2 \%$ sands, $74.6 \%$ silts, and $0.8 \%$ clays (Table 5 ). In contrast to other units, LU1 appears more sorted with overlapping of edges ("imbricated"), and sand-size grains that are marginally rounded. The appearance of this unit is likely the effects of a repeated influx of water followed by episodic evaporation resulting in rough-crusted surfaces similar to those described by Adams and Sada (2014) and Tollerud and Fantle (2014). LU1 is dissimilar to units LU2, LU3 and ALØ; sediment matrix is very thin laminated silt loam, indicative of a lacustrine water facies overlain a deeper unit (LU0).

The lowest unit (LU0) encountered was a preserved lacustrine feature of light brown clay (color hue 7.5YR 6/4) beginning at $\sim 186 \mathrm{~cm} \mathrm{bgs}$, dating to $13,090-12,990 \mathrm{cal}$ yrs BP at $186 \mathrm{~cm}$ bgs. It is important to note that this unit was not explored beyond $\sim 196 \mathrm{~cm}$ bgs owing to limited excavation techniques and safety. Sediments consisted of very thin laminated, fine-grained, imbricated clay-rich matrix composed of $<0.1 \%$ gravels, $44.2 \%$ sands, $53.1 \%$ silts and $2.6 \%$ clays (Table 5). The surface of LU0 contained surface-cracking ("mud-cracks") with evaporite-staining $(\sim 2.5 \mathrm{~cm})$, composed of well-sorted, firm, illuviation of argillic clays that were bedded, very plastic, and with particle sizes ranging between $1 \mathrm{~mm}$ and $2 \mu \mathrm{m}$ (Fig. 4E). This unit is progressively thicker with well-developed grains, ped-cutans, and blocky to prismatic structure. LU0 is clearly the result of chemical weathering of local silicate-bearing materials that produced primary clay deposits. LU0 is in stark contrast to other units; the matrix is composed of firm, very thin, laminated clays indicative of a long-standing, lacustrine, deep-water facies. Finally, the age of LU0 (13,090-12,990 cal yrs BP at $\sim 186 \mathrm{~cm}$ bgs $)$ places the surface firmly within the Pleistocene - Holocene transitional period.

\section{Discussion}

Major environmental events inferred from the sedimentological evidence at Ivanpah were compared to those of other studies from localities within or bordering the Mojave Desert. Documented events are likely associated with other recognized climatic shifts in the region, for instance, Wells et al. (2003) and others describe climatic shifts (drying events) within the region at ca. 9.2, 7.6, 8.2, 3.2 ka yrs BP with several minor shifts (wetting events) occurring ca. 2.5, 2.0, 1.5, 1.0 and 0.8 ka yrs BP, respectively (Cook et al., 2007; Harvey et al., 1999; Holmquist et al., 2016). Sediments from the LGL 5 excavation yielded data documenting multiple sequences with LU3d characterized as an aridisol sandy loam showing minor pedogenic processes (Figs. 4F/B). This unit's (LU3d) deposition and age is problematic though, evidence suggests it is younger than LU3a-c (1,050-1,025 cal yrs BP). Within this time frame, LU3d is probably linked to the wetting period ( $~ 800$ to 600 cal yrs BP) described by Mensing et al. (2008) (Fig. 4B). They documented that after the wetting period a drier, arid climate settled into this region. This drier period is likely responsible for ALØ; an aeolian sandy-silt bed deposited on the north-northeastern lateral of the Ivanpah valley.

Unit LU3a-c is a classic, near-shore littoral deposit of interbedded gravel and sand beach facies grading upward from basal to pea-sized gravels containing sands and minor silts as described by Bacon et al. (2006). LU3 (a-c) age of 1,050-1,025 cal yrs BP (Figs. 4F/B/C) places this unit within Holmquist et al. (2016) and Cook et al. (2007) period of warming over the Western United States, promoting increased monsoonal activities $\sim 1,000$ yrs BP. Other authors also describe sporadic wetting periods around the same time that caused monsoonal events (spring to winter) beginning 1,900 and ending 1,100 cal yrs BP (Negrini et al., 2006). Holmquist et al. (2016) 
further describes a period ending $\sim 1,280$ cal yrs BP when this region became significantly wetter; perhaps providing ideal stormy lake conditions to establish the beach zone of LU3 $3_{(\mathrm{a}-\mathrm{c})}$ that overlays the unit of LU2.

The surface unit LU2 is erosionally truncated with very minor desiccation cracking dating to 7,440-7,415 cal yrs BP at $\sim 78 \mathrm{~cm}$ bgs (Fig. 4F). Researchers Tollerud and Fantle (2014) studied similar environments documenting minor desiccation of playa surface and the stages at which mud-cracks form (Tollerud and Fantle, 2014). They also describe the subsurface of similar mud-cracked units as very thin laminated sediments resulting from a low energy suspension environment. Their efforts described surfaces similar to the minor desiccation of LU2 where the evolution of the mud-cracks promotes a smooth, evaporite-stained, strong surface with minor cracking of $\sim 3-5 \mathrm{~cm}$ long $0.5-1.5 \mathrm{~cm}$ thick, as seen with the surface of LU2.

Seismological evidence for LU2, a unit $\sim 46 \mathrm{~cm}$ thick, is indicative of a period of drying that occurred after a wetting phase (Fig. 4F). This unit is composed of classic fine, very thin laminated sediments commencing at $\sim 3-4 \mathrm{~cm}$ below the desiccated surface $\left(\sim 63 \mathrm{~cm}\right.$ bgs) to a depth of $\sim 109 \mathrm{~cm}$ bgs. It is dissimilar to $\mathrm{LU}_{(\mathrm{a}-\mathrm{d})}$ as it contains substantially more sands and silts, with no gravels. Evidence indicates that it is the result of a classic low energy depositional lacustrine environment similar to that described by Tollerud and Fantle (2014). Murchison and Mulvey (2000) and Patrickson et al. (2010) documented a drying events between 8,200 and 7,650 yrs BP causing recessional phases of the Great Salt Lake located northeast of Ivanpah. Furthermore, Blunt and Negrini et al. (2015) recognized events west-northwest of Ivanpah where a Tulare Lake shoreline (ca. $8,166-7,984$ and 8,857-9,008 cal yrs BP) began a recessional phase due to aridity as well. It is probable that LU2 is the result of those documented drying events and subsequent desiccation of LU2.

Below LU2 is LU1, a unit composed of very fine, very thin laminated sediments commencing at $\sim 109 \mathrm{~cm}$ to a depth of $\sim 185 \mathrm{~cm}$ bgs. Of importance at LU1 is the surface mud-cracks, which are $\sim 3-10+\mathrm{cm}$ long by a $\sim 2-5 \mathrm{~cm}$ thick; they are smooth, contain minor evaporite-staining, and have a strong surface (Fig. 4D). Below the surface cracking are very thin laminated sediments suggestive of a classic low energy depositional lacustrine environment as described by others (Negrini et al., 2006; Tollerud and Fantle, 2014). The surface ( $\sim 109 \mathrm{~cm}$ bgs) of LU1 yielded an age of 8,978-8,878 cal yrs BP with a lower depth $(\sim 180 \mathrm{~cm})$ dating to $9,485-9,405 \mathrm{cal}$ yrs BP (Fig. 4A).

LU1 links with documented regional shifts that affected the southwestern United Stated (e.g. Great Salt and Tulare lakes). Harvey et al. (1999) documented that during the early Holocene (ca. 9,500 -8,600 cal yrs BP), the jet stream moved north, and allowing monsoonal activity to enter the American Southwest inundating geographic basins. Such a shift in environmental conditions would have been the reason for the existence of LU1: a thick lacustrine facies. Following this event (Harvey et al. 1999), a drying episode described by Murchison and Mulvey (2000) likely led to the desiccation of the surface of LU1. Data suggests that the surface of LU1 is the product of the early Holocene lake termination event described by Murchison and Mulvey (2000).

The deepest unit, LU0 (13,090-12,990 cal yrs BP), represents a period of a long-standing water environment during the Pleistocene - Holocene transition (ca. 14,600-8,000 yrs BP) as described by Antinao and McDonald (2013). Moreover, at Tulare Lake, a period of increased wetting was documented (ca. 12,605 to 12,971 cal yrs BP), promoting perennial lakes within the region (Bacon et al., 2006, Kirby et al., 2015), possibly driving the wetting events at Lake Ivanpah. Furthermore, authors Harvey et al. (1999) describe an arid phase (ca. 13,000-10,500 yrs BP) following the perennial lake period, likely related to Bacon et al. (2006) and Kirby et al. (2015) work, resulting in the termination of pluvial lakes in this region. These drying events are probably the cause of the recessional phases identified at LU0 dating to 13,090 - 12,990 cal yrs BP (Fig. 4E). Evidence clearly puts unit LU0 within the early Pleistocene - Holocene transition; however, it is also feasible that LU0 is the result of the end of a late pluvial lake phase. Because of the limitation on the excavation imposed by the BLM, it is difficult to extrapolate much more from LU0, as additional work including deeper excavations would be required to fully describe this unit.

\section{Summary and Conclusions}

Dry lake systems located within the Mojave Desert are potentially good sites for alternative energy such as solar energy collection however, they have not been sufficiently studied for late Pleistocene - early Holocene lacustrine environments. Development could adversely impact valuable sedimentological resources contained within the shallow subsurface. This study used shallow sediment chemical proxies and characterization to assess subsurface conditions for buried lakebed features at Lake Ivanpah. The number and depth of shallow cores, and uses of trenching, to describe shallow sedimentary facies for this paper were adequate for limited delineation of wet and dry periods associated with lacustrine lake occupations, but does need more comprehensive data collection (especially subsurface data) and interpretation of this important period of desertification in recent 
geologic history.

Results at Lake Ivanpah illustrated that transitional lakes existed in the basin for two Holocene and one Pleistocene-Holocene transitional periods. Although there are no signs of visual wave-cutting at Ivanpah, chemical proxies and sediment characterization of site LGL5 showed a buried shoreline ("beach zone") and two lacustrine features. Furthermore, chemical proxies also identified two possible truncated shorelines at sites LGL7 and 11. With this in mind, evidence shows lake high-stands likely occurred at water depths of $\sim 1.8, \sim 5.3$ and $\sim 9.8 \mathrm{~m}$, respectively, in the Ivanpah valley. Lacustrine units identified beneath the surface at LGL5 were dated to ca. 1,050-1,025 (LU3a-c), 7,440-7,415 (LU2), and 9,485-9,405 (LU1) cal yrs BP with the deepest lake unit (LU0) dating to ca. 13,090-12,990 cal yrs BP. This evidence clearly shows that Lake Ivanpah has a significantly more complex history than just a single continuous lake episode of mid- to late-Holocene in age but rather, multiple episodes of lake stands, the oldest being a Pleistocene-Holocene (or older) transitional lake.

It is likely that other lacustrine units exist beneath the Ivanpah playa. The lack of visual evidence is most likely the result of an abrupt regional climatic shift $<1,000 \mathrm{yrs} \mathrm{BP}$, resulting in shoreline truncation and obliteration. Understanding environmental change in these basins is needed to better recognize climate changes during the late Pleistocene-early Holocene and regional desertification. Further studies of the surface of the Ivanpah and Roach dry lakes and surrounding landscapes is required to better characterize the overall basin. Finally, a more comprehensive surface and subsurface study is required to describe past conditions and depth of lacustrine environments at Ivanpah before extensive alternative energy developments disrupt shallow sedimentary evidence necessary for future research.

\section{Acknowledgments}

The authors would like to thank the personnel of the United States Department of interior, Bureau of Land management, Needles Office for their cooperation during this research. We would like to thank the numerous students from the College of Southern Nevada, Department of Physical Sciences, for their time in the field, laboratory and data interpretation. The NASA-CoP Grant (NNX14Q94A) provided funding to students at the College of Southern Nevada. We would also like to thank the reviewers whose time and expertise added great value to this paper and how it is presented.

\section{References}

Adams, K., \& Sada, D. W. (2014). Surface water hydrology and geomorphic characterization of playa lake systems: Implications for monitoring the effects of climate change. Journal of Hydrology, 510, 92-102. http://dx.doi.org/10.1016/j.jhydrol.2013.12.018

Adrian, M. H., Wigand, P. E., \& Wells, S. G. (1999). Response of Alluvial Fan Systems to the Late Pleistocene to Holocene Climatic Transition: Contrasts between the margins of pluvial lakes Lahontan and Mojave, Nevada and California, USA. Catena, 36(4), 255-281. http://dx.doi.org/10.1016/S0341-8162(99)00049-1

Antinao, J. L., \& McDonald, E. V. (2013). An enhanced role for the Tropical Pacific on the humid Pleistocene-Holocene transition in southwestern North America. Quaternary Science Reviews, 78, 319-341. http://dx.doi.org/10.1016/j.quascirev.2013.03.019

Bacon, S. N., Burke, R. M., Pezzopane, S. K., \& Jayko, A. S. (2006). Last glacial maximum and Holocene lake levels of Owens Lake, eastern California, USA. Quaternary Science Review, 25, 1264-1282. http://dx.doi.org/10.1016/j.quascirev.2005.10.014

Barker, S., Cacho, I., Benway, H., \& Tachikawa, K. (2005). Planktonic foraminiferal $\mathrm{Mg} / \mathrm{Ca}$ as a proxy for past oceanic temperatures: a methodological overview and data compilation for the Last Glacial Maximum. Quaternary Science Review, 24, 821-834. http://dx.doi.org/10.1016/j.quascirev.2004.07.016

Barker, S., Greaves, M., \& Elderfield, H. (2003). A study of cleaning procedures used for foraminiferal $\mathrm{Mg} / \mathrm{Ca}$ paleothermometry. Geochemistry, Geophysics, Geosystems, $\quad 4(9), \quad$ 1-20. http://dx.doi.org/10.1029/2003GC000559

Bauer, H. P., Beckett, P. H. T., \& Bie, S. W. (1972). A rapid gravimetric method for estimating calcium carbonate in soils. Plant and Soil, 37, 689-690. http://dx.doi.org/10.1007/BF00264189

Blunt, A. B., \& Negrini, R. M. (2015). Lake levels for the past 19,000 years from the TL05-4 cores, Tulare Lake, California, USA: geophysical and geochemical proxies. Quaternary International, 387, 122-130. http://dx.doi.org/10.1016/j.quaint.2015.07.001

Bull, W. B. (1991). Geomorphic responses to climatic change. Oxford University Press, Oxford, U. K. 
Carr, M. D., \& Pinkston, J. C. (1987). Geologic map of the Goodsprings District, southern Spring Mountains, Clark County, Nevada, Miscellaneous Field Studies Map - U. S. Geological Survey, MF-1514.

CH2MHILL (2009). Biological assessment for the Ivanpah solar electric generating system: Ivanpah (SEGS) project. Retrieved

from http://www.blm.gov/style/medialib/blm/ca/pdf/needles/lands_solar.Par.30845.File.dat/ ISEGS_Biological_Assessment_Dec09.pdf

Cléroux, C., Cortijo, E., Anand, P., Labeyrie, L., Bassinot, F., Caillon, N., \& Duplessy, J. C. (2008). Mg/Ca and $\mathrm{Sr} / \mathrm{Ca}$ ratios in planktonic foraminifera: Proxies for upper water column temperature reconstruction. Paleoceanography, 23(3), 1-16. http://dx.doi.org/10.1029/2007PA001505

Cook, E. R., Seager, R., Cane, M. A., \& Stahle, D. W. (2007). North American drought: reconstructions, causes, and consequences. Earth Sci. Rev., 81, 93-134. http://dx.doi.org/10.1175/JCLI4042.1

Enzel, Y., Brown, W. J., Anderson, R. Y., McFadden, L. D., \& Wells, S. G. (1992). Short-duration Holocene lakes in the Mojave River drainage basin, southern California. Quaternary Research, 38, 60-73. http://dx.doi.org/10.1016/0033-5894(92)90030-M

Enzel, Y., Wells, S. Lancaster, G., N. (2003). Late Pleistocene lakes along the Mojave River, southeast California. In Paleoenvironments and Paleohydrology of the Mojave and Great Basin Deserts (Y. Enzel, S. G. Wells, N. Lancaster, Eds.). Geological Society of American Special Paper, 368, 61-77. http://dx.doi.org/10.1130/0-8137-2368-X.1

Eugster, H. P., \& Kelts, K. (1983). Lacustrine chemical sediments. In: Goudie AS. Pye K. (Eds) Chemical sediments and geomorphology. Academic Press, London.

Garside, L. G., House, P. K., Burchfiel, B. C., \& Rowland, S. M. (2009). Preliminary geologic map of the Jean quadrangle, Clark County, Nevada. Nevada Bureau of Mines and Geology Open-file Map 09-5, scale $1: 24,000$.

Harvey, A. M., Wigand, P. E., \& Wells, S. G. (1999). Response of Alluvial Fan Systems to the Late Pleistocene to Holocene Climatic Transition: Contrasts between the Margins of Pluvial Lakes Lahontan and Mojave, Nevada and California, USA. Catena, 36(4), 255-281. http://dx.doi.org/10.1016/S0341-8162(99)00049-1

Holmquist, J. R., Booth, R. K., \& MacDonald, G. M. (2016). Boreal peatland water table depth and carbon accumulation during the Holocene thermal maximum, Roman Warm period, and Medieval Climate anomaly. $\begin{array}{llll}\text { Palaeogeography, } \quad \text { Palaeoclimatology, } & \text { Palaeoecology, } & \text { 444, }\end{array}$ http://dx.doi.org/10.1016/j.palaeo.2015.11.035

House, P. K., Buck, B. J., \& Ramelli, A. R. (2010). Geologic assessment of piedmont and playa flood hazards in the Ivanpah Valley area, Clark County, Nevada (online version): Nevada Bureau of Mines and Geology Report 53.

House, P. K., Ramelli, A. R., \& Buck, B. J. (2006). Surficial geologic map of the Ivanpah Valley area, Clark County, Nevada: Nevada Bureau of Mines and Geology Open-File Report 06-8, scale 1:50,000.

Jones, T. L., Brown, G. M., Raab, L. M., McVickar, J. L., Spaulding, W. G., Kennett, D. J., York, A. L., Walker, P. L. (1999). Environmental Imperatives Reconsidered: Demographic Crises in Western North America During The Medieval Climatic Anomaly. Current Anthropology, 40(2), 137-170. http://dx.doi.org/10.1086/200002

Kirby, M. E., Knell, E. J., Anderson, W. T., Lachniet, M. S., Palermo, J., Eeg, H., ...Hiner, C.A. (2015). Evidence for isolation and pacific forcing of late glacial through Holocene climate in the Central Mojave Desert (Silver Lake, CA). Quaternary Research, 84, 174-186. http://dx.doi.org/10.1016/j.yqres.2015.07.003

Kliem, P., Enters, D., Hahn, A., Ohendorf, C., Lise-Pronovost, A., St-Onge, G.,... PASADO Science Team (2012). Lithology, radiocarbon chronology and sedimentological interpretation of the lacustrine record from Laguna Potrok Aike, southern Patagonia. Quaternary Science Reviews, 71, 54-69. http://dx.doi.org/10.1016/j.quascirev.2012.07.019

Kober, B., Schwalb, A., Schettler, G., \& Wessels, M. (2007). Constraints on paleowater dissolved loads and on catchment weathering over the past $16 \mathrm{ka}$ from ${ }^{87} \mathrm{Sr} /{ }^{86} \mathrm{Sr}$ ratios and $\mathrm{Ca} / \mathrm{Mg} / \mathrm{Sr}$ chemistry of freshwater ostracode tests in sediments of Lake Constance, Central Europe. Chemical Geology, 240(3-4), 361-376. http://dx.doi.org/10.1016/j.chemgeo.2007.03.005

Litwin, R. J., Smoot, J. P., \& Smith, G. I. (1999). Calibrating late Quaternary terrestrial climate 
signals: Radiometrically dated pollen evidence from the southern Sierra Nevada, USA. Quaternary Science Reviews, 18, 1151-71.http://dx.doi.org/10.1016/S0277-3791(98)00111-5

May, J. H., Barrett, A., Cohen, T. J., Jones, B. G., Price, D., \& Gliganic, L. A. (2015). Late Quaternary evolution of a playa margin at Lake Frome, South Australia. Journal of Arid Environments, 122, 93-108. http://dx.doi.org/10.1016/j.jaridenv.2015.06.012

McKee, E. D., \& Weir, A. (1953). Terminology for stratification and cross-stratification. Bull. Geol. Soc. Amer., 64, 381-390.

Mehringer, P. J., \& Warren, C. N. (1976). Marsh, dune, and archaeological chronology, Ash Meadows, Amargosa Desert, Nevada. In Elston, R., Ed., "Holocene environmental change in the Great Basin." Nevada Archaeological Survey Research Paper, 6, 120-150.

Mensing, S., Smith, J., Norman, K. B., \& Allan, M. (2008). Extended drought in the Great basin of western North America in the last two millennia reconstructed from pollen record. Quaternary International, 188(1), 79-89. http://dx.doi.org/10.1016/j.quaint.2007.06.009

Mifflin, M. D., \& Wheat, M. M. (1979). Pluvial Lakes and Estimated Pluvial Climates of Nevada. Nevada Bureau of Mines and Geology Bulletin 94.

Morse1, J. W., Wang, Q., \& Tsio, M. Y. (1997). Influences of temperature and Mg:Ca ratio on $\begin{array}{lllll}\mathrm{CaCO}_{3} \text { precipitates } & \text { from } & \text { Geawater. } & \text { 85-87. }\end{array}$ http://dx.doi.org/10.1130/0091-7613(1997)025<0085:IOTAMC $>2.3 . C O ; 2$

Murchison, S. B., \& Mulvey, W. E. (2000). Late Pleistocene and Holocene shoreline stratigraphy on Antelope Island. Utah Geological Survey Misc. Pubulication, 1, 77-83. http://dx.doi.org/10.1016/j.yqres.2009.12.006

Negrini, R. M., Wigand, P. E., Draucker, S., Gobalet, K., Gardner, J. K., Sutton, M. Q., \& Yohe, R. M. (2006). The Rambla highstand shoreline and the Holocene lake-level history of Tulare Lake, California, USA. Quaternary Science Reviews, 25, 1599-1618. http://dx.doi.org/10.1016/j.quascirev.2005.11.014

Nishizawa, S. (2010). The Bonneville lake basin shoreline records of large lake and abrupt climate change events. Unpublished dissertation, University of Utah, Department of Geography.

Noble, P., Zimmerman, S., Ball, I., Adams, K., Maloney, J., Smith, S. (2016). Late Holocene subalpine lake sediments record a multi-proxy shift to increased aridity at $3.65 \mathrm{kyr}$ BP, following a millennial - scale neopluvial interval in the Lake Tahoe watershed and western Great Basin, USA. Geophysical Research Abstracts 18.

Patrickson, S. J., Sack, D., Brunelle, A. R., \& Moser, K. A. (2010). Late Pleistocene to early Holocene lake level and paleoclimate insights from Stansbury Island, Bonneville basin, Utah. Quaternary Research, 73, 237-246. http://dx.doi.org/10.1016/j.yqres.200 9.12.006

Pigati, J. S., Miller, D. M., Bright, J. E., Mahan, S. A., Nekola, J. C., \& Paces, J. B. (2011). Chronology, sedimentology, and microfauna of groundwater discharge deposits in the central Mojave Desert, Valley Wells, California. Geological Society of America Bulletin, 123, 2224-2239.

Quade, J., Forester, R. M., \& Whelan, J. F. (2003). Late Quaternary Paleoclimatic and Paleotemperature Change in southern Nevada. In Paleoenvironments and Paleohydrology of the Mojave and southern Great Basin Deserts (Y. Enzel, S. G. Wells, and N. Lancaster, Eds.). Geological Society of American Special Paper, 368, 165-188. Boulder, CO.

Quade, J., Mifflin, M. D., Pratt, W. L., McCoy, W., \& Burckle, L. (1995). Fossil spring deposits in the southern Great Basin and their implications for changes in water-table levels near Yucca Mountain, Nevada, during Quaternary time. Geological Society of America Bulletin, 107, 213-230.

Ramelli, A. R., House, P. K., \& Buck, B. J. (2006). Preliminary Surficial Geologic Map of the Ivanpah Valley Part of the Roach and desert 7.5' Quadrangles, Clark County, Nevada. Nevada Bureau of Mines and Geology. Open-file Report 611-F. Carson City, NV.

Regenberg, M., Steph, S., Nurnberg, D., Tiedemann, R., Garbe-Schonberg, D. (2009). Calibrating Mg/Ca ratios of multiple planktonic foraminiferal species with ${ }^{18} \mathrm{O}$-calcification temperatures: Paleothermometry for the upper water column. Earth and Planetary Science Letters, 278, 324-336. http://dx.doi.org/10.1016/j.epsl.2008.12.019

Reheis, M., \& Redwine, J. L. (2008). Lake Manix shoreline and Afton Canyon terraces: Implications for incicion of Afton Canyon. Geological Society of America, 439, 227-259. http://dx.doi.org/10.1130/2008.2439(10) 
Reis, J. (2004). Effects of ambient $\mathrm{Mg} / \mathrm{Ca}$ ratio on $\mathrm{Mg}$ fraction in calcareous marine invertebrates: A record of the oceanic $\mathrm{Mg} / \mathrm{Ca}$ ratio over the Phanerozoic. Geological Society of America, 32(11), 981-984.

Retallack, G. J. (1988). Field recognition of paelosols. Geological Society of America, Special paper 216.

Robinson, M. C., Flint, S., \& Spaulding, W. G. (1999). Molycorp, Inc. Mountain Pass Mine cultural resources investigations testing and evaluation report for CA-Sbr9387, CA-SBr-9388, and CA-SBr9389/H, Ivanpah Dry Lake, San Bernardino County, California. Applied Earth Works, Hemet, CA. Retrieved from https://www.scribd.com/doc/314014653/Robinson-et-al-1999-Ivanpah-CA-Report

Rodrigues-Filho, S., \& Muller, G. (1999). A Holocene sedimentary record from Lake Silvana, SE Brazil: evidence for paleoclimatic changes from mineral, trace-metal, and pollen data. Volume 88 of Lecture notes in earth sciences. Springer, p. 96.

Rodrigues-Filho, S., Behling, H., Irion, G., \& Muller, G. (2001). Evidence for Lake Formation as a Response to an Inferred Holocene Climatic Transition in Brazil. Quaternary Research, 57(1), 131-137. http://dx.doi.org/10.1006/qres.2001.2281

Sack, D. (1995). The shoreline preservation index as a relative-age dating tool for late Pleistocene shorelines: An example from the Bonneville basin, USA. Earth Surf Process Landf, 20, 363-377. http://dx.doi.org/10.1002/esp.3290200406

Sack, D. (2001). Shoreline and basin configuration techniques in paleolimnology, in Last, W.M., J.P. Smol (Eds), 2001. Tracking environmental change using lake sediments. Vol. 1: Basin analysis, coring and chronological techniques. Kluwer Academic Publishers, Dordrecht, The Netherlands.

Sanchi, L., Menot, G., \& Bard, E. (2015). Environmental controls on paelo-pH at mid-latitudes: A case study from Central and Eastern Europe. Paleogeography, Paleoclimatology, Paleoecology, 417, 458-466. http://dx.doi.org/10.1016/j.palaeo.2014.10.007

Schmidt. K. M., \& McMackin, M. (2006). Preliminary surficial geologic map of the Mesquite Lake 30' x 60' Quadrangle, California and Nevada. U.S. Geological Survey Open File Report 2006-1035. Denver, CO.

Schnurrenberger, D., Russell, J., \& Kelts, K. (2003). Classification of lacustrine sediments based on sedimentary components. J Paleolimnology, 29, 141-154. http://dx.doi.org/10.1023/A:1023270324800

Shapiro, R. (2016). Camelid record of Mesquite Lake, California: Impact of earliest Holocene climate change. The 30th Annual Desert Symposium, p. 41.

Spaulding, W. G. (1990). Vegetational and climatic development of the Mojave Desert: The last glacial maximum to the present. In "Packrat middens: The last 40,000 years of biotic change" ( J.L. Betancourt, T.R. Van Devender, and P.S. Martin, Eds.). University of Arizona Press, Tucson. pp. 166-199.

Spaulding, W. G., \& Graumlich, L. J. (1986). The last pluvial climatic episodes in the deserts of southwestern North America. Nature, 320, 441-444.

Stumm, W., Morgan, J. J. (1996). Aquatic Chemistry Chemical Equilibria and Rates in Natural Waters. 3rd Ed., John Wiley \& Sons, Inc., New York, p. 1022.

Sun, Z., Xu, G., Hao, T., Huang, Z., Fang, H., \& Wang, G. (2015). Release of heavy metals from sediment bed under wave-induced liquefaction. Marine Pollution Bulletin, 79(1-2), 209-216. http://dx.doi.org/10.1016/j.marpolbul.2015.06.015

Tardy, Y., Roquin, C. (1992). Geochemistry and evolution of lateritic landscapes. In: C.R.M. Butt and H. Zeegers (Editors). Handbook of Exploration Geochemistry, 4. Regolith Exploration Geochemistry in Tropical and Subtropical Terrains. Elsevier, Amsterdam, pp. 407-443.

Tchakerian V. P., \& Lancaster, N. (2002). Late Quaternary arid/humid cycles in the Mojave Desert and western Great Basin of North America. Quaternary Science Reviews, 21, 799-810. http://dx.doi.org/10.1016/S0277-3791(01)00128-7

Thompson, R. S., Whitlock, C., Bartlein, P. J., Harrison, S. P., \& Spaulding, W. G. (1993). Climatic changes in the western United States since 18,000 yr B.P. In "Global climates since the last glacial maximum" (H. E. Wright, Jr., J. E. Kutzbach, T. Webb, III, W. F. Ruddiman, F. A. Street-Perrott, and P. J. Bartlein, Eds.), pp. 469-513. University of Minnesota Press, Minneapolis, MN.

Tollerud, H. J., \& Fantle, M. S. (2014). The temporal variability of centimeter-scale surface roughness in a playa dust source: Synthetic aperture radar investigation of playa surface dynamics. Remote 
Sensing of Environment, 154, 285-297. http://dx.doi.org/10.1016/j.rse.2014.08.009

US Geological Survey (USGS) (1985). Ivanpah Lake, Calif. - Nev. 7.5-minute Topographic Quadrangle. Provisional Edition. Lakewood, CO.

USEPA. (1997). SW-846, Test Methods for Evaluating Solids and Wastes - Physical/Chemical Methods, U.S. Environmental Protection Agency. December, CD-Rom.

Waring, G. A. (1920). Ground Water in Pahrump, Mesquite, and Ivanpah Valleys Nevada and California. WaterSupply Paper, 450-C. pp. 51-85.

Watanabe, T., Winter, A., \& Oba, T. (2001). Seasonal changes in sea surface temperature and salinity during the Little Ice Age in the Caribbean Sea deduced from $\mathrm{Mg} / \mathrm{Ca}$ and ${ }^{18} \mathrm{O} /{ }^{16} \mathrm{O}$ ratios in coral. Marine Geology, 173, 21-35. http://dx.doi.org/10.1016/S0025-3227(00)00166-3

Wells, S. G., Brown, W. J., Enzel, Y., Anderson, R.Y., \& McFadden, L. D. (2003). Late Quaternary geology and paleohydrology of pluvial Lake Mojave, southern California. In Paleoenvironments and Paleohydrology of the Mojave and southern Great Basin Deserts (Y. Enzel, S. G. Wells, and N. Lancaster, eds.). Geological Society of American Special Paper, 368, 79-114.

Whitney, J. W., Breit, G. N., Buckingham, S. E., Reynolds, R. L., Bogle, R. C., Luo, L., Goldstein, H. L., \& Vogel, J. M. (2015). Aeolian responses to climate variability during the past century on Mesquite Lake Playa, Mojave Desert. Geomorph, 230, 13-25. http://dx.doi.org/10.1016/j.aeolia.2016.09.001

\section{Supplementary Data}

Locations

\begin{tabular}{|c|c|c|c|c|c|c|c|c|c|c|c|c|c|}
\hline \multirow{10}{*}{$\begin{array}{c}\text { Al } \\
\text { Units } \\
\text { mg } \\
\text { kg-1 }\end{array}$} & Depth & 1 & 2 & 3 & 4 & 5 & 6 & 7 & 8 & 9 & 10 & 11 & 12 \\
\hline & 10 & 11,600 & 12,500 & 16,500 & 18,750 & 28,860 & 27,850 & 33,160 & 4,015 & 36,920 & 6,700 & 44,580 & 31,200 \\
\hline & 20 & 20,550 & 21,000 & 17,000 & 16,600 & 36,290 & 41,920 & 44,760 & 7,200 & 38,670 & 3,500 & 43,010 & 45,920 \\
\hline & 30 & 20,600 & 20,300 & 24,800 & 19,500 & 49,670 & 40,010 & 44,750 & 9,350 & 41070 & 7,650 & 41,920 & 46,010 \\
\hline & 40 & 20,900 & 23,500 & 24,100 & 17,100 & 39,370 & 32,550 & 34,760 & 8,200 & 40,960 & 7,360 & 36,410 & 33,010 \\
\hline & 50 & 20,400 & 21,050 & 20,800 & 16,200 & 32,220 & 35,600 & 26,130 & 5,800 & 36,000 & 6,080 & 31,440 & 32,000 \\
\hline & Mean & 18810 & 19670 & 20640 & 17630 & 37282 & 35586 & 36712 & 6913 & 38724 & 6258 & 39472 & 37628 \\
\hline & STDEV & 4035 & 4188 & 3863 & 1426 & 7990 & 5674 & 8028 & 2081 & 2301 & 1657 & 5443 & 7638 \\
\hline & MAX & 20900 & 23500 & 24800 & 19500 & 49670 & 41920 & 44760 & 9350 & 41070 & 7650 & 44580 & 46010 \\
\hline & MIN & 11600 & 12500 & 16500 & 16200 & 28860 & 27850 & 26130 & 4015 & 36000 & 3500 & 31440 & 31200 \\
\hline \multirow{10}{*}{$\begin{array}{c}\text { Fe } \\
\text { Units } \\
\text { mg kg-1 }\end{array}$} & Depth & 1 & 2 & 3 & 4 & 5 & 6 & 7 & 8 & 9 & 10 & 11 & 12 \\
\hline & 10 & 17200 & 15560 & 15700 & 9050 & 23340 & 21810 & 25920 & 5150 & 24800 & 8100 & 29000 & 23400 \\
\hline & 20 & 17350 & 16265 & 16805 & 13350 & 25020 & 27250 & 27190 & 8305 & 25800 & 8950 & 29100 & 28630 \\
\hline & 30 & 16550 & 24550 & 26400 & 24800 & 29780 & 26600 & 27450 & 18250 & 26210 & 9250 & 28700 & 29110 \\
\hline & 40 & 27650 & 27800 & 26900 & 25900 & 26690 & 21880 & 24080 & 29750 & 25830 & 7800 & 25600 & 23000 \\
\hline & 50 & 27500 & 26350 & 26500 & 17750 & 25050 & 24680 & 21760 & 16800 & 24270 & 7900 & 23300 & 22800 \\
\hline & Mean & 21250 & 22105 & 22461 & 18170 & 25976 & 24444 & 25280 & 15651 & 25382 & 8400 & 27140 & 25388 \\
\hline & STDEV & 5782 & 5774 & 5684 & 7251 & 2434 & 2554 & 2377 & 9632 & 812 & 657 & 2591 & 3190 \\
\hline & MAX & 27650 & 27800 & 26900 & 25900 & 29780 & 27250 & 27450 & 29750 & 26210 & 9250 & 29100 & 29110 \\
\hline & MIN & 16550 & 15560 & 15700 & 9050 & 23340 & 21810 & 21760 & 5150 & 24270 & 7800 & 23300 & 22800 \\
\hline \multirow{10}{*}{$\begin{array}{c}\text { K } \\
\text { Units } \\
\text { mg kg-1 }\end{array}$} & Depth & 1 & 2 & 3 & 4 & 5 & 6 & 7 & 8 & 9 & 10 & 11 & 12 \\
\hline & 10 & 22270 & 27820 & 26790 & 10150 & 8815 & 8280 & 9581 & 1920 & 9144 & 9250 & 9513 & 8065 \\
\hline & 20 & 22405 & 30330 & 29300 & 17705 & 9734 & 9576 & 9611 & 2614 & 9753 & 9575 & 9404 & 9439 \\
\hline & 30 & 29480 & 25040 & 28000 & 21395 & 9620 & 9600 & 9784 & 2831 & 9461 & 16200 & 9564 & 9217 \\
\hline & 40 & 32890 & 34050 & 28650 & 24980 & 9532 & 8635 & 9341 & 2214 & 9312 & 10800 & 9093 & 8900 \\
\hline & 50 & 30380 & 31670 & 27390 & 20150 & 9070 & 8556 & 7913 & 2402 & 9448 & 8800 & 1280 & 8850 \\
\hline & Mean & 27485 & 29782 & 28026 & 18876 & 9354 & 8929 & 9246 & 2396 & 9424 & 10925 & 7771 & 8894 \\
\hline & STDEV & 4863 & 3479 & 993 & 5539 & 393 & 616 & 762 & 352 & 224 & 3041 & 3633 & 522 \\
\hline & MAX & 32890 & 34050 & 29300 & 24980 & 9734 & 9600 & 9784 & 2831 & 9753 & 16200 & 9564 & 9439 \\
\hline & MIN & 22270 & 25040 & 26790 & 10150 & 8815 & 8280 & 7913 & 1920 & 9144 & 8800 & 1280 & 8065 \\
\hline
\end{tabular}




\begin{tabular}{|c|c|c|c|c|c|c|c|c|c|c|c|c|c|c|c|}
\hline \multirow{10}{*}{$\begin{array}{c}\text { V } \\
\text { Units } \\
\text { mg kg-1 }\end{array}$} & \multicolumn{2}{|c|}{ Depth } & \multicolumn{2}{|l|}{1} & 2 & 3 & 4 & 5 & 6 & 7 & 8 & 9 & 10 & 11 & 12 \\
\hline & \multicolumn{2}{|c|}{10} & 46 & & 39 & 39 & 16 & 55 & 46 & 65 & 8.7 & 51 & 12 & 79 & 57 \\
\hline & \multicolumn{2}{|c|}{20} & 44 & & 37 & 37 & 28 & 57 & 65 & 71 & 14 & 69 & 15 & 83 & 78 \\
\hline & & & 48 & & 42 & 41 & 34 & 77 & 61 & 71 & 19 & 67 & 16 & 82 & 78 \\
\hline & & & 48 & & 44 & 43 & 41 & 67 & 49 & 62 & 18 & 61 & 11 & 68 & 69 \\
\hline & & & 44 & & 45 & 40 & 31 & 61 & 43 & 58 & 13 & 63 & 14 & 57 & 66 \\
\hline & & & 46 & & 41 & 40 & 30 & 63 & 53 & 65 & 15 & 62 & 14 & 74 & 70 \\
\hline & ST & EV & 2 & & 3.4 & 2.2 & 9.2 & 8.9 & 9.7 & 5.7 & 4.1 & 7 & 2.1 & 11.1 & 8.8 \\
\hline & & & 48 & & 45 & 43 & 41 & 77 & 65 & 71 & 19 & 69 & 16 & 83 & 78 \\
\hline & & & 44 & & 37 & 37 & 16 & 55 & 43 & 58 & 9 & 51 & 11 & 57 & 57 \\
\hline & Depth & 1 & & 2 & 3 & 4 & 5 & 6 & 7 & & 8 & 9 & 10 & 11 & 12 \\
\hline Mg & 10 & 6700 & & 700 & 6650 & 4480 & 8640 & 8299 & 9180 & & 519 & 9698 & 3952 & 10680 & 8814 \\
\hline Units & 20 & 6710 & & 750 & 6600 & 6100 & 9790 & 11170 & 10510 & & 370 & 9535 & 4025 & 10480 & 10520 \\
\hline mg kg-1 & 30 & 6600 & & 675 & 6800 & 6600 & 12200 & 11050 & 10710 & & 380 & 10430 & 4143 & 9030 & 10630 \\
\hline & 40 & 6850 & & 100 & 6900 & 6650 & 10790 & 9114 & 9178 & & 092 & 10370 & 3870 & 9100 & 9100 \\
\hline & 50 & 7400 & & 700 & 6700 & 6100 & 9170 & 9490 & 7849 & & 700 & 9553 & 3658 & 8574 & 8900 \\
\hline & Mean & 6852 & & 185 & 6730 & 5986 & 10118 & 9825 & 9485 & & 012 & 9917 & 3930 & 9573 & 9593 \\
\hline & STDEV & 319 & & 668 & 120 & 882 & 1412 & 1251 & 1164 & & 391 & 446 & 182 & 944 & 903 \\
\hline & MAX & 7400 & & 100 & 6900 & 6650 & 12200 & 11170 & 10710 & & 380 & 10430 & 4143 & 10680 & 10630 \\
\hline & MIN & 6600 & & 675 & 6600 & 4480 & 8640 & 8299 & 7849 & & 519 & 9535 & 3658 & 8574 & 8814 \\
\hline & Depth & 1 & & 2 & 3 & 4 & 5 & 6 & 7 & & 8 & 9 & 10 & 11 & 12 \\
\hline $\mathbf{C a}$ & 10 & 25700 & & 4400 & 22800 & 4300 & 2505 & 20300 & 21300 & & 8950 & 22940 & 7420 & 30430 & 17360 \\
\hline Units & 20 & 26100 & & 6650 & 25450 & 1755 & 2431 & 33480 & 24840 & & 9000 & 22900 & 7950 & 30910 & 24070 \\
\hline mg kg-1 & 30 & 26050 & & 8490 & 24450 & 1695 & 4121 & 34500 & 27850 & & 9100 & 29500 & 9270 & 27320 & 24590 \\
\hline & 40 & 21700 & & 4100 & 22050 & 1237 & 3560 & 23750 & 23810 & & 10330 & 29050 & 8100 & 25340 & 22100 \\
\hline & 50 & 27600 & & 3750 & 22150 & 1108 & 3139 & 26510 & 18120 & & 9070 & 21120 & 7800 & 21360 & 22010 \\
\hline & Mean & 25430 & & 9478 & 23380 & 1245 & 3151 & 27708 & 23184 & & 9290 & 25102 & 8108 & 27072 & 22026 \\
\hline & STDEV & 2210 & & 312 & 1504 & 5352 & 7148 & 6153 & 3678 & & 584 & 3883 & 697 & 3927 & 2852 \\
\hline & MAX & 27600 & & 4100 & 25450 & 1755 & 4121 & 34500 & 27850 & & 10330 & 29500 & 9270 & 30910 & 24590 \\
\hline & MIN & 21700 & & 4400 & 22050 & 4300 & 2431 & 20300 & 18120 & & 8950 & 21120 & 7420 & 21360 & 17360 \\
\hline & $\mathrm{De}_{1}$ & & 1 & 2 & 2 & 3 & 4 & 5 & 6 & 7 & & 9 & 10 & 11 & 12 \\
\hline $\mathbf{Z n}$ & 1 & & 85 & 7 & 77 & 75 & 32 & 59 & 59 & 75 & & 69 & 21 & 82 & 66 \\
\hline Units & 2 & & 85 & 8 & & 31 & 61 & 73 & 82 & 83 & & 70 & 23 & 82 & 84 \\
\hline mg kg-1 & 3 & & 80 & 6 & & 32 & 70 & 98 & 80 & 82 & & 77 & 31 & 81 & 87 \\
\hline & 4 & & 92 & 8 & & 33 & 76 & 83 & 62 & 67 & & 76 & 28 & 72 & 80 \\
\hline & 5 & & 88 & 8 & & 44 & 62 & 80 & 65 & 56 & & 68 & 24 & 71 & 77 \\
\hline & $\mathrm{Me}$ & & 86 & 8 & & 79 & 60 & 79 & 70 & 73 & & 72 & 25 & 78 & 79 \\
\hline & STD & & 4.4 & 7. & & 2 & 16.9 & 14.3 & 10.6 & 11.3 & & 4.2 & 4 & 5.6 & 8.1 \\
\hline & MA & & 92 & 8 & 99 & 33 & 76 & 98 & 82 & 83 & & 77 & 31 & 82 & 87 \\
\hline & $\mathrm{Ml}$ & & 80 & 6 & & 74 & 32 & 59 & 59 & 56 & & 68 & 21 & 71 & 66 \\
\hline & Dept & 1 & 1 & 2 & 3 & 4 & 5 & 6 & 7 & 8 & & 9 & 10 & 11 & 12 \\
\hline As & 10 & 2. & .5 & 0.9 & 2 & 1.1 & 0.03 & 0.01 & 2.9 & 0.02 & & $3.60 \mathrm{E}-05$ & 0.9 & 0.06 & 0.06 \\
\hline Units & 20 & 5 . & .5 & 1.4 & 1.3 & 1.1 & 0.09 & 0.03 & 0.4 & 0.01 & & $1.60 \mathrm{E}-05$ & 2.8 & 0.01 & 0.01 \\
\hline mg kg-1 & 30 & 0 . & .8 & 5.3 & 5.4 & 1.8 & 0.05 & 0.03 & 1.9 & 0.02 & & $3.60 \mathrm{E}-05$ & 0.9 & 0.03 & 0.04 \\
\hline & 40 & 1. & 8 & 6.1 & 4.3 & 2.3 & 0.01 & 0.01 & 1.8 & 0.01 & & $1.60 \mathrm{E}-05$ & 1 & 0.01 & 0.01 \\
\hline & 50 & 4. & .3 & 1.1 & 3.2 & 1.9 & 0.04 & 0.04 & 1.4 & 0.01 & & $1.60 \mathrm{E}-05$ & 0.9 & 0.01 & 0.01 \\
\hline & Mear & 3 & & 3 & 3 & 2 & 0 & 0 & 2 & 2 & & 0 & 0 & 1 & 0 \\
\hline & STDE & 1 . & 9 & 2.5 & 1.7 & 0.5 & 0 & 0 & 0.9 & 0.9 & & 0 & 0 & 0.8 & 0 \\
\hline & MAX & 6 & & 6 & 5 & 2 & 0 & 0 & 3 & 3 & & 0 & 0 & 3 & 0 \\
\hline & MIN & 1 & 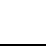 & 1 & 1 & 1 & 0 & 0 & 0 & 0 & & 0 & 0 & 1 & 0 \\
\hline
\end{tabular}




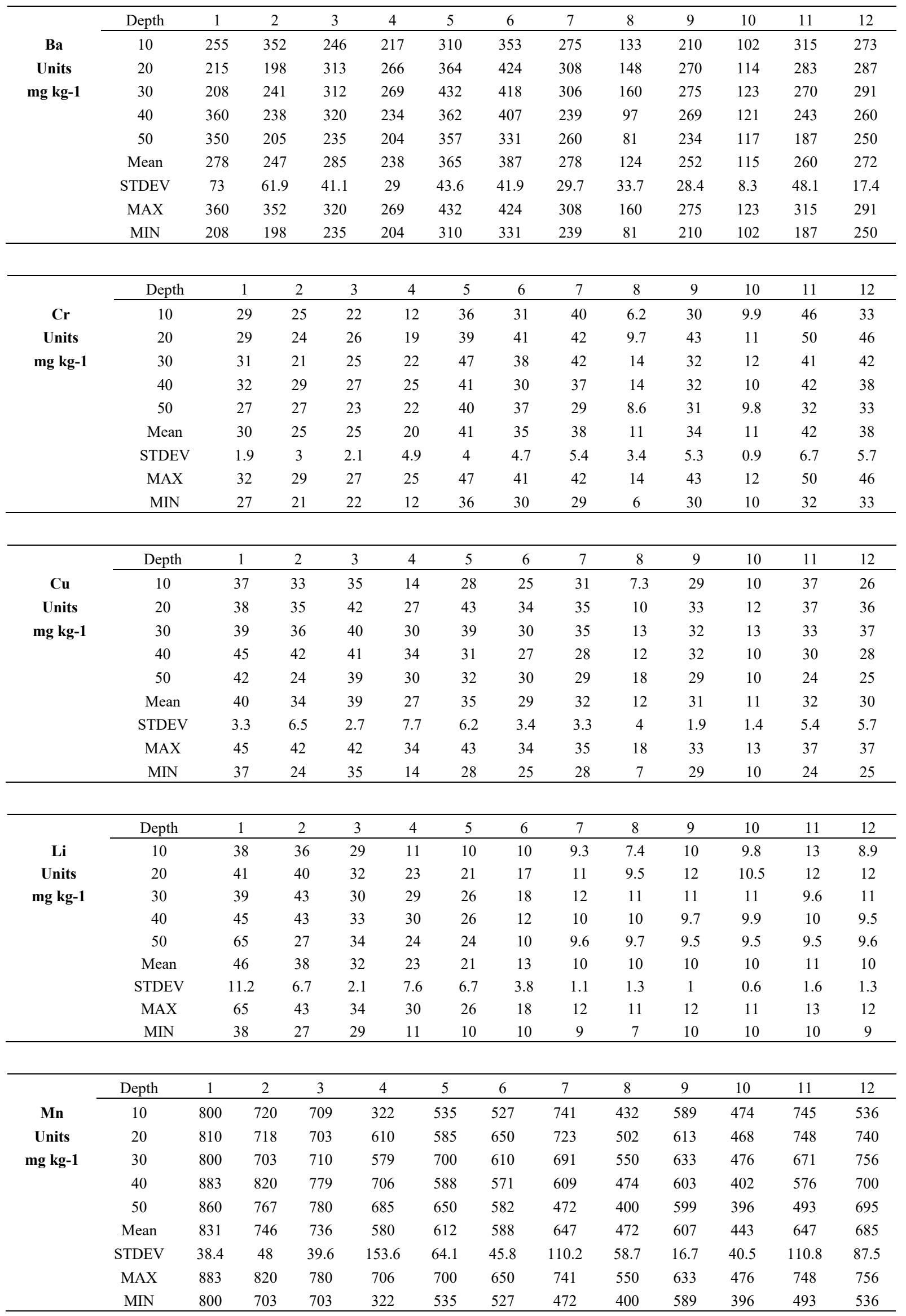




\begin{tabular}{|c|c|c|c|c|c|c|c|c|c|c|c|c|c|}
\hline & Depth & 1 & 2 & 3 & 4 & 5 & 6 & 7 & 8 & 9 & 10 & 11 & 12 \\
\hline $\mathbf{N i}$ & 10 & 26 & 20 & 23 & 12 & 21 & 20 & 21 & 7.4 & 23 & 10 & 29 & 22 \\
\hline Units & 20 & 24 & 20 & 23 & 20 & 24 & 27 & 27 & 10 & 26 & 11 & 29 & 30 \\
\hline \multirow[t]{8}{*}{ mg kg-1 } & 30 & 25 & 23 & 26 & 22 & 33 & 26 & 27 & 13 & 27 & 12 & 30 & 30 \\
\hline & 40 & 28 & 25 & 25 & 25 & 27 & 21 & 22 & 12 & 27 & 11 & 25 & 27 \\
\hline & 50 & 25 & 20 & 24 & 20 & 24 & 24 & 18 & 9.1 & 22 & 10 & 21 & 23 \\
\hline & Mean & 26 & 22 & 24 & 20 & 26 & 24 & 23 & 10 & 25 & 11 & 27 & 26 \\
\hline & STDEV & 1.5 & 2.3 & 1.3 & 4.8 & 4.5 & 3 & 3.9 & 2.2 & 2.3 & 0.8 & 3.8 & 3.8 \\
\hline & MAX & 28 & 25 & 26 & 25 & 33 & 27 & 27 & 13 & 27 & 12 & 30 & 30 \\
\hline & MIN & 24 & 20 & 23 & 12 & 21 & 20 & 18 & 7 & 22 & 10 & 21 & 22 \\
\hline & Depth & 1 & 2 & 3 & 4 & 5 & 6 & 7 & 8 & 9 & 10 & 11 & 12 \\
\hline $\mathbf{P b}$ & 10 & 33 & 14 & 21 & 9.5 & 11 & 13 & 12 & 6.2 & 14 & 5.2 & 19 & 17 \\
\hline Units & 20 & 24 & 13 & 20 & 10 & 14 & 16 & 17 & 7.9 & 18 & 6.1 & 17 & 18 \\
\hline \multirow[t]{7}{*}{ mg kg-1 } & 30 & 23 & 17 & 24 & 13 & 15 & 16 & 19 & 8.6 & 16 & 6.4 & 15 & 18 \\
\hline & 40 & 32 & 17 & 25 & 15 & 13 & 12 & 10 & 5.5 & 14 & 5.1 & 13 & 16 \\
\hline & 50 & 30 & 16 & 20 & 15 & 12 & 14 & 9.8 & 4.6 & 12 & 5.3 & 12 & 15 \\
\hline & Mean & 28 & 15 & 22 & 13 & 13 & 14 & 14 & 7 & 15 & 6 & 15 & 17 \\
\hline & STDEV & 4.6 & 1.8 & 2.3 & 2.6 & 1.6 & 1.8 & 4.2 & 1.7 & 2.3 & 0.6 & 2.9 & 1.3 \\
\hline & MAX & 33 & 17 & 25 & 15 & 15 & 16 & 19 & 9 & 18 & 6 & 19 & 18 \\
\hline & MIN & 23 & 13 & 20 & 10 & 11 & 12 & 10 & 5 & 12 & 5 & 12 & 15 \\
\hline
\end{tabular}

\begin{tabular}{|c|c|c|c|c|c|c|c|c|c|c|c|c|c|c|}
\hline \multirow{10}{*}{$\begin{array}{c}\text { Ti } \\
\text { Units } \\
\text { mg kg-1 }\end{array}$} & Depth & 1 & 2 & 3 & 4 & 5 & 6 & 7 & 8 & 9 & & 10 & 11 & 12 \\
\hline & 10 & 480 & 292 & 323 & 253 & 741 & 609 & 860 & 145 & 810 & & 270 & 1100 & 780 \\
\hline & 20 & 439 & 384 & 387 & 206 & 680 & 941 & 871 & 237 & 860 & & 311 & 1130 & 1058 \\
\hline & 30 & 455 & 636 & 470 & 386 & 1250 & 841 & 990 & 409 & 961 & & 371 & 1008 & 1008 \\
\hline & 40 & 480 & 591 & 416 & 331 & 1100 & 625 & 810 & 391 & 851 & & 331 & 940 & 950 \\
\hline & 50 & 473 & 526 & 389 & 276 & 921 & 610 & 648 & 267 & 800 & & 307 & 740 & 860 \\
\hline & Mean & 465 & 486 & 397 & 290 & 938 & 725 & 836 & 290 & 856 & & 318 & 984 & 931 \\
\hline & STDEV & 18 & 144.2 & 53.2 & 69.9 & 239.4 & 155.6 & 124 & 110.4 & 63.9 & & 6.9 & 155.6 & 112.1 \\
\hline & MAX & 480 & 636 & 470 & 386 & 1250 & 941 & 990 & 409 & 961 & & 371 & 1130 & 1058 \\
\hline & MIN & 439 & 292 & 323 & 206 & 680 & 609 & 648 & 145 & 800 & & 270 & 740 & 780 \\
\hline \multirow{10}{*}{$\begin{array}{c}\mathrm{SO}_{4}{ }^{2-} \\
\text { Units } \\
\text { mg kg-1 }\end{array}$} & Depth & 1 & 2 & 3 & 4 & 5 & 6 & 7 & 8 & - & & 10 & 11 & 12 \\
\hline & 10 & 6878 & 1523 & 1520 & 687 & 3531 & 1189 & 1081 & 854 & 65 & & 1854 & 1520 & 690 \\
\hline & 20 & 9556 & 7046 & 9891 & 680 & 687 & 1844 & 1523 & 168 & 13 & & 1520 & 1525 & 1390 \\
\hline & 30 & 12066 & 29303 & 8531 & 12903 & 695 & 6870 & 1021 & 118 & 35 & & 520 & 680 & 1300 \\
\hline & 40 & 30290 & 29500 & 12066 & 20250 & 519 & 1022 & 884 & 855 & 15 & & 499 & 180 & 520 \\
\hline & 50 & 26950 & 9054 & 9054 & 2010 & 2528 & 1691 & 851 & 519 & 18 & & 488 & 181 & 510 \\
\hline & Mean & 17148 & 15285 & 8212 & 7306 & 1592 & 2523 & 1072 & 102 & 5 & & 976 & 817 & 882 \\
\hline & STDEV & 10697 & 13178 & 3977 & 8869 & 1361 & 2454 & 269 & 441 & 45 & & 660 & 675 & 430 \\
\hline & MAX & 30290 & 29500 & 12066 & 20250 & 3531 & 6870 & 1523 & 168 & 13 & & 1854 & 1525 & 1390 \\
\hline & MIN & 6878 & 1523 & 1520 & 680 & 519 & 1022 & 851 & 519 & 18 & 0 & 488 & 180 & 510 \\
\hline \multirow{10}{*}{$\begin{array}{c}\mathrm{Cl}^{-} \\
\text {Units } \\
\text { mg kg-1 }\end{array}$} & Depth & 1 & 2 & 3 & 3 & 4 & 5 & 6 & 7 & 8 & 9 & 10 & 11 & 12 \\
\hline & 10 & 88553 & 162170 & 301 & 068 & 1280 & 530 & 870 & 1060 & 226 & 282 & 207 & 2081 & 2295 \\
\hline & 20 & 41920 & 87950 & 172 & 407 & 3018 & 1238 & 4925 & 730 & 2230 & 664 & 197 & 630 & 4858 \\
\hline & 30 & 38374 & 158900 & 170 & 078 & 2700 & 220 & 392 & 910 & 730 & 668 & 227 & 186 & 123 \\
\hline & 40 & 46097 & 140400 & 531 & 182 & 1980 & 520 & 1031 & 377 & 150 & 179 & 214 & 146 & 197 \\
\hline & 50 & 50360 & 58900 & 117 & 818 & 1690 & 280 & 640 & 550 & 110 & 160 & 211 & 143 & 210 \\
\hline & Mean & 53061 & 121664 & 162 & 911 & 2134 & 558 & 1572 & 725 & 689 & 391 & 211 & 637 & 1537 \\
\hline & STDEV & 20343 & 45973 & 912 & 45 & 716 & 405 & 1890 & 273 & 897 & 256 & 11 & 833 & 2071 \\
\hline & MAX & 88553 & 162170 & 301 & 068 & 3018 & 1238 & 4925 & 1060 & 2230 & 668 & 227 & 2081 & 4858 \\
\hline & MIN & 38374 & 58900 & 531 & 82 & 1280 & 220 & 392 & 377 & 110 & 160 & 197 & 143 & 123 \\
\hline
\end{tabular}




\begin{tabular}{cccccccccccccc}
\hline & Depth & 1 & 2 & 3 & 4 & 5 & 6 & 7 & 8 & 9 & 10 & 11 & 12 \\
\cline { 2 - 12 } CaCO $_{3}$ & 10 & 172 & 153 & 148 & 132 & 177 & 482 & 490 & 141 & 474 & 120 & 549 & 501 \\
Units & 20 & 169 & 156 & 186 & 165 & 470 & 465 & 483 & 127 & 468 & 143 & 470 & 477 \\
mg kg-1 & 30 & 124 & 105 & 149 & 151 & 410 & 475 & 420 & 153 & 470 & 120 & 453 & 470 \\
& 40 & 163 & 225 & 158 & 169 & 422 & 480 & 485 & 155 & 460 & 122 & 480 & 420 \\
& 50 & 223 & 289 & 141 & 155 & 478 & 469 & 474 & 133 & 470 & 123 & 463 & 360 \\
& Mean & 170 & 186 & 156 & 154 & 391 & 474 & 470 & 142 & 468 & 126 & 483 & 446 \\
& STDEV & 35.3 & 71.9 & 17.6 & 14.5 & 123.4 & 7.2 & 28.8 & 12.2 & 5.2 & 9.8 & 38.2 & 56.2 \\
& MAX & 223 & 289 & 186 & 169 & 478 & 482 & 490 & 155 & 474 & 143 & 549 & 501 \\
& MIN & 124 & 105 & 141 & 132 & 177 & 465 & 420 & 127 & 460 & 120 & 453 & 360 \\
\hline
\end{tabular}

\begin{tabular}{|c|c|c|c|c|c|c|c|c|c|c|c|c|c|}
\hline & Depth & 1 & 2 & 3 & 4 & 5 & 6 & 7 & 8 & 9 & 10 & 11 & 12 \\
\hline pH & 10 & 7.21 & 7.3 & 7.21 & 7.46 & 7.39 & 6.94 & 7.62 & 8.05 & 6.81 & 8.15 & 7.31 & 6.84 \\
\hline Units & 20 & 7.41 & 7.32 & 7.41 & 7.66 & 7.3 & 6.84 & 7.63 & 8.02 & 7.35 & 8.29 & 7.37 & 6.89 \\
\hline \multirow[t]{5}{*}{ S.U } & 30 & 7.54 & 7.23 & 7.54 & 7.86 & 7.62 & 7.33 & 7.27 & 8.25 & 6.97 & 8.5 & 7.47 & 7.23 \\
\hline & 40 & 8.05 & 7.43 & 8.05 & 7.67 & 7.15 & 7.42 & 7.16 & 8.34 & 7.02 & 8.31 & 7.22 & 7.01 \\
\hline & 50 & 7.96 & 7.47 & 7.96 & 7.68 & 7.81 & 7.62 & 7.34 & 8.25 & 7.64 & 8.39 & 7.54 & 6.97 \\
\hline & Mean & 7.6 & 7.4 & 7.6 & 7.7 & 7.5 & 7.2 & 7.4 & 8.2 & 7.2 & 8.3 & 7.4 & 7 \\
\hline & STDEV & 0.4 & 0.1 & 0.4 & 0.1 & 0.3 & 0.3 & 0.2 & 0.1 & 0.3 & 0.1 & 0.1 & 0.2 \\
\hline
\end{tabular}

\section{Supplementary Tables}

Core Locations

\begin{tabular}{cll}
\hline Sample ID & Latitude & Longitude \\
\hline 1 & $35.518350^{\circ}$ & $-115.379900^{\circ}$ \\
2 & $35.518400^{\circ}$ & $-115.359616^{\circ}$ \\
3 & $35.519900^{\circ}$ & $-115.354383^{\circ}$ \\
4 & $35.521400^{\circ}$ & $-115.345967^{\circ}$ \\
5 & $35.523617^{\circ}$ & $-115.341933^{\circ}$ \\
6 & $35.523900^{\circ}$ & $-115.340566^{\circ}$ \\
7 & $35.524267^{\circ}$ & $-115.338217^{\circ}$ \\
8 & $35.524367^{\circ}$ & $-115.337933^{\circ}$ \\
9 & $35.524600^{\circ}$ & $-115.336166^{\circ}$ \\
10 & $35.524483^{\circ}$ & $-115.333917^{\circ}$ \\
11 & $35.525400^{\circ}$ & $-115.333417^{\circ}$ \\
12 & $35.525933^{\circ}$ & $-115.330558^{\circ}$ \\
\hline
\end{tabular}

\section{Copyrights}

Copyright for this article is retained by the author(s), with first publication rights granted to the journal.

This is an open-access article distributed under the terms and conditions of the Creative Commons Attribution license (http://creativecommons.org/licenses/by/4.0/). 